\author{
Оливье АЗАМ \\ Высшая нормальная школа (Париж), \\ CeLiSo - Центр тингвистики в Сорбонне (Франция, Париж) \\ azamoam@club-internet.fr
}

\title{
Изображение произношения французского языка XVIII века в фонетической части русского перевода «Французской грамматики» Пеплиера. Несколько замечаний о предлагаемой картине
}

В 1752 г. появилась первая русская грамматика французского языка, «Новая французская грамматика» В. Е. Теплова, перевод с немецкого анонимной «Neue und vollständige Französische Grammatik» 1749 г. Почти сорок лет спустя, в 1780 г., была опубликована в Москве в Университетской типографии переведенная с немецкого преподавателем немецкого и французского языков московской Славяно-греко-латинской академии «Французская грамматика ${ }^{1}$ при которой Исправнъйшій Словарь, Дружескіе разговоры, Пословицы, Достойныя примъчанія Исторіи и пристойныя на разные случаи пи́сма. Изданная на нъмецкомъ языкъ Г. Пепліеромъ. А на Россійской переведенная п.с.к. Федоромъ Сокольскимъ». В 1788 г. вышло ее второе издание 2.

«Новая французская грамматика» Теплова и «Французская грамматика» Пеплиера - лучшие переводные грамматики французского языка, которые русский читатель 1780-х гг. имел в своем распоряжении. Неслучайно эти труды имеют немецкое происхождение: со времен Петра Великого просвещенная российская элита была знакома прежде всего с немецким, и до появления грамматики Теплова к изучению французского переходили после предварительного освоения немецкого. В своей статье о преподавании французского в России в XVIII в. В. Ржеуцкий и С. Власов отмечают, что за несколько десятилетий до перевода Grammaire Royale Françoise Пеплиера Coкольским в библиотеке царевича Алексея Петровича имелся экземпляр этой книги на немецком языке. «Из-за отсутствия учебников французского на русском языке царевич был вынужден изучать французский язык через немецкий, которым он уже владел» [Rjéoutski, Vlassov 2013: 2].

Переводы обеих грамматик на русский позволили русскому читателю знакомиться с французским без предварительного владения третьим языком. Но, увы, перевод не мог полностью стереть следы влияния языка-посредника. В своем тщательном исследовании «Новой французской грамматики» В. Е. Теплова Н. В. Карева и М. Л. Сергеев напоминают, что «переводчику следовало постоянно иметь в виду соотношение не только русской и французской, но также русской и немецкой, немецкой и французской грамматической

\footnotetext{
1 Дальше «Французская грамматика» без дополнительных указаний всегда обозначает русский перевод грамматики Пеплиера.

2 Мы сохранили оригинальную транскрипцию Сокольским фамилии автора. Дальше «Пеплиер» обозначает издания русского перевода, a Pepliers латинскими буквами - издания немецкого оригинала.
} 
(...) систем[ы]» [Карева, Сергеев 2016: 59]. Ф. Сокольский оказался в той же самой ситуации, что В. Теплов, и польза его перевода для читателя, не владеющего немецким, во многом зависела от его способности адаптировать для русской публики описание французского, составленное для носителей немецкого.

Настоящая работа посвящена фонетической части грамматики Пеплиера, которая составляет первую главу «О буквах и словах, их изображеніи и выговорђ» первой части учебника «О правописаніи и произношеніи». Анализируя эти первые важнейшие страницы книги ${ }^{3}$, мы поставим себя на место русского читателя и постараемся выяснить, насколько верна предложенная Сокольским картина французского произношения XVIII в. Для этого мы остановимся на нескольких особенно трудных или спорных моментах фонетического описания и транскрипций Сокольского.

Для правильной оценки орфоэпической части русской версии грамматики Пеплиера необходимо иметь в виду три важных момента.

1) Переводный характер грамматики. При попытке изобразить звуки одного языка системой письма другого языка неточности неминуемы. Они могут быть сведены к минимуму, если предлагаемые транскрипции однозначны и соблюдены с последовательностью. Но если русский переводчик недостаточно знаком с французским и опирается для передачи звуков французского на немецкие транскрипции, тогда в переводе неточности немецкого оригинала как будто возводятся в квадрат.

2) Французская фонетика второй половины XVIII в. находится в переходном состоянии. Орфоэпическая норма «Великого века» Людовика XIV достаточно хорошо известна и прочна. Если верить грамматикам, орфоэпическая норма XVIII в. сохраняет большинство особенностей, которые отличают ее от современной нормы: релевантность оппозиции слогов по признаку долготы, произношение фонемы /r/, звук l тоӥillée, преимущество [wع] над [wa] и другие. Но уже началось большинство тех процессов, которые приведут к современному произношению. Когда именно произошли изменения? Большинство авторов французских нормативных трудов большие консерваторы. Часто затруднительно понять, когда уже известное, но считающееся некорректным десятью годами ранее изменение стало признанной нормой. Перед тем, как оценить точность транскрипций Сокольского, придется сначала установить, что́ именно он должен был изобразить. Это и составит наибольшую часть нашей работы.

3) Перевод Сокольского вышел в 1780 г. В основе грамматики Пеплиера лежит «Французская грамматика по новому плану» («Grammaire françoise sur un plan nouveau») отца Бюффье, преподавателя коллежа Людовика Великого,

\footnotetext{
319 страниц в первом издании 1780 г., 17 во втором издании 1788 г. Что касается первой, фонетической главы, эти издания можно считать практически идентичными. Даже опечатки чаще всего не исправлены во втором издании. Единственное значительное различие относится как раз к фонетическим транскрипциям. Как правило, конечный ъ, который употребляется систематически в первом издании, исчез из второго. Тем не менее, «освобожденной» таким образом графеме Сокольский не придает никакого условного фонетического значения во втором издании.
} 
опубликованная в 1709 г. При активности процессов фонетических перемен на протяжении XVIII в. 71 год - это очень большой срок. Какое именно состояние языка отражают транскрипции Сокольского? Произношение времен Бюффье? Эпохи сочинения грамматики Пеплиера? Или годов перевода Сокольского?

В вышеупомянутом труде В. Е. Теплова Н. В. Карева и М. Л. Сергеев подробно рассматривали соотношение «Новой францусской грамматики» и ее немецкого источника. Они пришли к выводу, что «адаптация текста для русского читателя не была существенной и последовательной» [Карева, Сергеев 2016: 58].

Перспектива настоящей работы другая. В центре нашего внимания окажется не соотношение перевода с метаязыком оригинала, а соотношение русского перевода со своим предметом - французским языком XVIII в. ${ }^{4}$.

\section{1. План орфоэпической части «Французской грамматики»}

В своем переводе Сокольский ничуть не отступает от плана оригинала, который в свою очередь воспроизводит в общих чертах план почти всех нормативных французских источников, в том числе и Бюффье 5 . В русских и немецких изданиях Пеплиера первая глава грамматики состоит

- из приведения французского алфавита с транскрипцией французских названий букв;

- из списка гласных и согласных звуков;

- из перечня всех букв или сочетаний букв, приведенных в алфавитном порядке, обозначающих звуки французского языка. Каждой букве или сочетанию букв посвящается рубрика, содержащая описание обозначаемого звука и

${ }^{4}$ Как все авторы XVII-XVIII вв., в своем описании французского произношения Пеплиер постоянно путает три уровня анализа — графему, звук (конкретную реализацию фонемы) и фонему. Постоянно встречаются такие формулировки, как «A произносится какъ...; Aient, ayent на концЊ глаголовъ произносится какъ...» и т. д. Разумеется, с лингвистической точки зрения правильно было бы «А читается как». Имеется в виду описание обозначенного буквой или сочетанием букв звука, который является конкретной реализацией определенной фонемы. Но читателю «Французской грамматики» не до фонемы, его интересует только соотношение между тем, что написано, и конкретным обозначаемым звуком. Поэтому в настоящем комментарии Пеплиера последуем его примеру и будем говорить о «произношении» букв, имея в виду обозначаемые ими звуки, осознавая неправильность такой формулировки. Говоря о гласных и согласных, чаще всего будем иметь в виду конкретный звук и тогда будем употреблять мужской род. Когда речь идет о гласной или согласной вообще (как о фонеме, так и о ее реализации и обозначении ее буквами), будем употреблять женский род, а для обозначения буквы - женский или же средний, по примеру Сокольского. Для фонетической транскрипции в прямых скобках употребляются общепринятые во французских нормативных грамматиках и словарях знаки международного фонетического алфавита. По умолчанию в настоящей работе под фонетикой французского языка имеется в виду орфоэпическая норма XVII-XVIII вв. Без дополнительных указаний транскрипции в международном фонетическом алфавите отражают произношение XVII-XVIII вв., а не современное французское произношение. Устойчивое место ударения во французских словах - на предпоследнем слоге в словах, заканчивающихся на [ә], и на последнем слоге в остальных случаях не указывается. Для фонетической транскрипции русских звуков употребляется кириллическая транскрипция, а не международный фонетический алфавит. Таким образом, сразу видно, о звуках какого языка идет речь.

${ }^{5}$ См. [Buffier 1709]. 
его транскрипцию русскими буквами. Чаще всего приводятся примеры с транскрипцией. В этой части наиболее длинные статьи посвящены буквам $E$ (для различия открытого, закрытого и безгласного $e$ ), $H$ и $S$ (для отличия тех, «которые не произносятся», от тех, «которые произносятся»).

- Как в большинстве французских источников, последние страницы главы составляют небольшой трактат «о произношеніи согласныхъ словъ на конць $(\mathrm{sic} !)^{6}$ ». В немецком оригинале эти страницы разделяются на три кратких Haupt-Regeln и один последний раздел под названием Besondere Regeln, в которых рассматривается в алфавитном порядке произношение конечных согласных. В русском же переводе третье «главное правило» слилось с «особенными правилами» немецкой версии, и оставшиеся части небольшого трактата просто отмечены цифрами 1, 2, 3 без текста (в немецком цифры отсутствуют). Ошибка не исправлена во втором издании. К ней и сводится вся разница между немецким оригиналом и русской версией первой главы книги.

Как в оригинале, так и в переводе глава о произношении заканчивается на следующем замечании:

ПРИМЪЧАНІЕ: въ сей главЪ о произношеніи буквъ гдъ сей * знакъ поставленъ, то разумъть надобно, что произношенію того слова съ буквою точно изобразить было не можно, но оныхъ произношенію учиться должно изустно [Пеплиер 1780: 18-19].

NB. Wo neben hie obstehenden Artickeln dieses Zeichen * beygesetzt worden, solches bedeutet, daß die eigentliche Aussprache selbiger Sylben, mit unsern Buchstaben nicht könne vorgebildet, sondern von einer lebendigen Stimme müsse erlernet werden [Pepliers 1749: 13].

Это предупреждение повторяется в русских изданиях в сноске при транскрипции слова heureux: «Произношеніе еи учиться должно изустно» [Пеплиер 1780: 7].

6 Вместо «согласныхъ на концђ словъ». В издании 1788 года опечатка остается неисправленной. 


\section{2. Оральные гласные}

\section{1. Список французских оральных гласных звуков и их тран- скрипция русскими и немецкими буквами в грамматике Пеплиера}

Та бли и а 1

\section{Транскрипции оральных гласных звуков ${ }^{7}$}

\begin{tabular}{|c|c|c|c|c|}
\hline [a] & $\mathbf{a}$ & $\begin{array}{l}A . \text { произносится какъ Россій- } \\
\text { ское } a\end{array}$ & a & $\begin{array}{l}\text { A, wie ein teutsches lautes } \\
a\end{array}$ \\
\hline $\begin{array}{l}\text { [garsõ] garçon } \\
\text { [sa] ça }\end{array}$ & & $\begin{array}{l}\text { гарсон } \\
\text { са }\end{array}$ & ве $A$ не & $\begin{array}{l}\text { e пиводится }{ }^{8} \text {. } \\
\text { garßon } \\
\text { ßа } \\
\end{array}$ \\
\hline & $\mathbf{a}$ & произносится какъ долгое $a$ & $\mathbf{a}$ & $\begin{array}{l}\text { als ein einfaches langes } a \\
\text { ausgesprochen }\end{array}$ \\
\hline [a:3ə] aage, âge & & \multicolumn{3}{|c|}{ Транскрипиии приведенного примера нет } \\
\hline $\begin{array}{l}\text { [e] } \\
\text { [preã:bylə] } \\
\text { préambule }\end{array}$ & e & $\begin{array}{l}\boldsymbol{E} \text { fermé запертое или острое } \\
\text { произносится как } e \\
\text { преамбюль }\end{array}$ & eh & $\begin{array}{l}\text { E fermé, das geschlossene } \\
\text { oder scharfe } e \text { wie } e h \\
\text { prehambüle }\end{array}$ \\
\hline $\begin{array}{r}{[\mathbf{e}:]} \\
{[\text { parle:] parlez }}\end{array}$ & e & парле & eh & parleh \\
\hline $\begin{array}{l}\quad[\varepsilon] \\
\text { [ferme] fermer } \\
{[\text { fermə] ferme }} \\
\text { [3eryzalem] } \\
\text { Ierusalem } \\
\text { [Egzamen] examen }[\text { imen] } \\
\text { hymen }\end{array}$ & !e & $\begin{array}{l}\boldsymbol{E} \text { ouvert oткрытое или дол- } \\
\text { гое произносится какъ э } \\
- \\
\text { фэрмъ (ferme) } \\
\text { !жерузалемъ } \\
\text { !ексаменъ } \\
\text { !имень (1780), гимен (1788) }\end{array}$ & $! \mathrm{e}^{9}$ & $\begin{array}{l}\text { E ouvert, das offene oder } \\
\text { lange e, wie } \ddot{a} \\
\text { färmeh (fermer); } \\
- \\
\text { !Scherüsalem } \\
\text { examen } \\
\text { himen (sic) }\end{array}$ \\
\hline $\begin{array}{l}\quad[\varepsilon:] \\
{[\text { be:tə] bête }} \\
{\left[\text { pre:te] prêter }{ }^{11}\right.}\end{array}$ & э & $\begin{array}{l}\text { естьли на ономъ стои́тъ } \\
\text { облеченіе }{ }^{10} \\
\text { бэтъ } \\
\text { прэте } \\
\end{array}$ & !äh & $\begin{array}{l}\text { wenn es mit einem } \\
\text { circumflex gezeichnet ist } \\
\text { bäte } \\
\text { prähteh }\end{array}$ \\
\hline [pe:nə] peine & ень & $\begin{array}{l}\text { Перед /n/ звук [ع(:)] } \\
\text { транскрибируется в русском } \\
\text { переводе как ень } \\
\text { пень }\end{array}$ & !äh & $\begin{array}{l}\text { В немецком же оригина- } \\
\text { ле транскрипция [ع(:)n] } \\
\text { не отличается. } \\
\text { pähnе }\end{array}$ \\
\hline
\end{tabular}

${ }^{7}$ В таблицах слева направо: 1) французский звук и примеры; 2) русская транскрипция звука; 3) описание звука и транскрипция звука в русском переводе; 4) немецкая транскрипция звука; 5) описание звука и транскрипция звука в немецком переводе.

${ }^{8}$ Когда примеров при описании звука нет, приводятся примеры из других статей.

9 Восклицательным знаком отмечается сочетание букв, конкретно встречающееся в транскрипции некоторых примеров, но отличающееся от того, которое изначально предлагалось для передачи данного звука.

10 Пеплиер ошибочно отождествляет открытость е с его долготой.

11 В немецком оригинале и издании 1780 года prêter. В русском издании 1788 года с опечаткой - préter. 


\begin{tabular}{|c|c|c|c|c|}
\hline 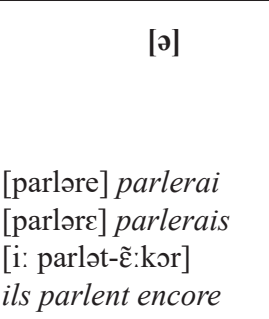 & $\begin{array}{l}\mathbf{e} \\
\boldsymbol{\emptyset}^{12} \\
\text { e } \\
\varnothing\end{array}$ & \begin{tabular}{|l}
$\boldsymbol{E}$ тиёt безгласное $e$ весьма \\
тихо выговаривается, или \\
чтобы и совсьмъ онаго не \\
слышно было. \\
- \\
парлере (parlerois, sic!) \\
ипарл-танкоръ
\end{tabular} & e & $\begin{array}{l}\text { E muët, das stumme oder } \\
\text { stille } e \text { wird sehr dunckel, } \\
\text { oder gar nicht gehöret } \\
\text { parlereh (parleroi) } \\
- \\
\text { i parle tankor }\end{array}$ \\
\hline [sœr] sœur & iôe & $\begin{array}{l}\boldsymbol{E} \boldsymbol{u} \text { произносится такъ какъ } \\
\text { бы сіи три Россійскія буквы, } \\
i \hat{e} е \text { однимъ слогомъ произне- } \\
\text { сти должно (...) } \\
\left({ }^{*}\right) \text { Произношеніе eи учиться } \\
\text { должно изустно. } \\
\boldsymbol{O e u}, \text { какъ îo } \\
\text { cîoеръ }\end{array}$ & !öh & $\begin{array}{l}\boldsymbol{E} \boldsymbol{u}, \text { wie ö } \\
\boldsymbol{O e u}, \text { wie ö }\end{array}$ \\
\hline $\begin{array}{l}\text { [œ:] или [ø:] }{ }^{13} \\
\text { [bœ:rrə] beurre } \\
\text { [œ:rə] heure }\end{array}$ & iôe & \begin{tabular}{|l} 
бiôepъ \\
iôepъ
\end{tabular} & öh & $\begin{array}{l}\text { böhre } \\
\text { öhre }\end{array}$ \\
\hline $\begin{array}{c}{[\boldsymbol{\sigma}:]} \\
{[\mathrm{y}(:) \mathrm{r} \varnothing:] \text { heureux }} \\
\end{array}$ & iôe & юpiôe* & $\ddot{0}$ & ürö \\
\hline $\begin{array}{c}\text { [i] } \\
\text { [inimitje] inimitié }\end{array}$ & и & $\begin{array}{l}\boldsymbol{I} \text {, произносится какъ } \\
\text { Россійское } i \text { (sic) } \\
\text { инимитіе }\end{array}$ & $\mathbf{i}$ & $\begin{array}{l}\text { I, wie ein teutsches } i \\
\text { inimitjeh }\end{array}$ \\
\hline $\begin{array}{l}\text { [vi:] vie } \\
\text { [ri:] rient }\end{array}$ & и & $\begin{array}{l}\text { Естьли на концъ сло́ва [без- } \\
\text { гласное е] гласную предъ со- } \\
\text { бою имъетъ, то не выговари- } \\
\text { вается, а предъидущей слогъ } \\
\text { бываетъ долгой } \\
\text { ви } \\
\text { ри }\end{array}$ & ih & $\begin{array}{l}\text { Wenn es am Ende des } \\
\text { Worts einen Vocalem vor } \\
\text { sich hat, wird es gar nicht } \\
\text { gehöret, die vorhergehende } \\
\text { Sylbe aber etwas lang aus- } \\
\text { gesprochen } \\
\text { wih } \\
\text { rih } \\
\end{array}$ \\
\hline $\begin{array}{r}{[\mathbf{0 ]}} \\
{[\text { proze] projet }} \\
\end{array}$ & $\mathbf{o}$ & $\begin{array}{l}\boldsymbol{O} \text { произносится какъ Руское } o \\
\text { прожэ }\end{array}$ & o & $\begin{array}{l}\boldsymbol{O}, \text { wie ein teutsches } O \\
\text { proschä }\end{array}$ \\
\hline [bo:] beau ${ }^{\text {[0:] }}$ & o & $\begin{array}{l}\text { Eau произносится, какъ } o \\
\text { бо }\end{array}$ & $\begin{array}{c}\mathbf{o} \\
! \text { oh } \\
\end{array}$ & $\begin{array}{l}\text { Eau, wie } o \\
\text { boh }\end{array}$ \\
\hline $\begin{array}{l}\text { [u] } \\
{[\mathrm{bu}] \text { bout }} \\
{[\mathrm{kur}] \text { cour }}\end{array}$ & $\mathbf{y}$ & $\begin{array}{l}\text { Ои произносится какъ } y \\
\text { бу } \\
\text { курь }\end{array}$ & ! uh & $\begin{array}{l}\text { Ou, wie u } \\
\text { bu } \\
\text { kuhr }\end{array}$ \\
\hline [bu:] boue ${ }^{[\mathbf{u}:]}$ & $\mathbf{y}$ & $\begin{array}{l}\text { Oue какъ } y \text { долгое } \\
\text { бу }\end{array}$ & uh & $\begin{array}{l}\text { Oue, wie ein langsames } u \\
\text { buh }\end{array}$ \\
\hline${ }_{[\mathrm{by}] \text { but }}{ }^{[\mathbf{y}]}$ & ${ }^{*} \mathbf{1 0}$ & $\begin{array}{l}\text { *U какъ } ю \\
\text { бю }\end{array}$ & $\ddot{\mathbf{u}}$ & $\begin{array}{l}\mathbf{U} \text {, wie } \ddot{u} \\
\text { bü }\end{array}$ \\
\hline
\end{tabular}

\footnotetext{
12 В этом столбце ø значит «не транскрибируется».

13 Точное произношение долгого еи в beurre, heure в XVIII в. ([œ:] или [ø:]) нельзя восстановить с полной уверенностью.
} 


\section{2. Состав системы оральных гласных звуков во французском языке XVIII в.}

На основе современного французского языка в приведенных здесь таблицах отличаются по качеству звуки [а] и [a], [о] и [о], [œ] и [ø]. Но такие различия остаются для XVII и XVIII веков гипотетическими. Не существует однозначных доказательств в пользу различия по признаку тембра в описаниях нормативных источников XVII в. Оральные гласные отличались тогда по признаку долготы, оперативному на фонологическом уровне до конца XVIII в., но утратившему свою релевантность в XIX в. Эндрэ [Hindret 1687: 133-134] и вслед за ним Оливе [Olivet 1760: 87-89] ${ }^{14}$ приводят не исчерпывающие, но достаточно внушительные списки омонимических словоформ, которые отличаются только долготой гласной. Источники XVII-XVIII вв. Шифле, Эндрэ, Ла Туш и Ренье-Демарэ, Валлар, Оливе, Феро, Домерг [Chiflet 1659: 172-200; Hindret 1687: 132-197; La Touche, Regnier Desmarais 1730: 69-92; Vallart 1744: 39-47; Olivet 1760; Féraud 1768; Domergue 1778: 198-212] единогласно различают долгие и краткие гласные, краткие и долгие дифтонги, но источники XVII в. и большинство источников XVIII в. не уточняют, имеет ли долгота гласной влияние на ее качество. Для XVII в. можно с уверенностью восстановить только следующую систему оральных согласных звуков:

\begin{tabular}{|c|c|}
\hline Краткие & Долгие \\
\hline [a] patte & [a:] pâte \\
\hline [e] chanté & [e:] chantée \\
\hline$[\varepsilon]$ clerc $[\mathrm{kler}]$ & {$[\varepsilon:]$ clercs $[\mathrm{kle}: \mathrm{r}]$} \\
\hline [ə] petit & \\
\hline [œ] peur & [œ:] beurre \\
\hline [i] il [i] & [i:] ils [i:] \\
\hline [o] pomme & [o:] paume \\
\hline$[\mathrm{u}]$ cou & [u:] cous \\
\hline [y] venu & [y:] venue \\
\hline [we] Roi & [we:] Rois \\
\hline
\end{tabular}

В вышеприведенной таблице знаки $o, a, \propto$ употребляются условно, без указания на открытость или закрытость гласной, которая к этому времени однозначно установлена только для [е] и [ع].

\section{3. Долгие и краткие гласные и их тембр}

Оппозиция гласных по долготе так значительна, что она занимает отдельные разделы в нормативных произведениях XVII в. В орфоэпическом трактате Эндрэ, например, 3-я глава о долготе слогов занимает целых 65 страниц. Проблема долготы считалась в те времена одним из трех главных фонетиче-

14 Olivet цитируется здесь по изданию 1760 г., но первое издание вышло в 1737 г. 
ских вопросов, заслуживающих особого анализа наряду с произношением конечных согласных и произношением трех видов $E^{15}$.

По тому особому значению, которое пуристы придают долготе слогов, понятно, что в живой речи оппозиция по долготе уже где-то начинает утрачиваться: «Правильность произношения во многом зависит от соблюдения долгих и кратких, а почти все, включая ученых и просвещенных людей, делают ошибки в этой области: парижане обычно произносят последние краткие слоги как долгие, и нормандцы, бретонцы, жители области Анжу и все жители городов, расположенных вдоль Луары, произносят краткие предпоследние слоги как долгие. Поэтому не будет лишним дать правила [произношения долгих и кратких слогов]» ${ }^{16}$.

Но система еще прочна, и лет через сорок после учебника Эндрэ выйдет знаменитый «Трактат о французской просодии» члена Французской академии аббата д’Оливе (1682-1768). Эта книга станет эталоном французской просодии на следующие полвека.

Как ни странно, Пеплиер практически не затрагивает вопрос о долготе гласных. В первой главе долгота гласных эксплицитно упоминается только два раза, в связи с орфографией. Правда, мимоходом эксплицитно признается возможность существования любой долгой гласной, но упоминается только одна из нескольких позиций, в которых гласная обязательно произносится долгой: «E тиёt (...) естьли въ конце сло́ва гласную предъ собою имъетъ, то не выговаривается, а предъидущей слогъ бываеть долгой: vie, ви; rient ри» [Пеплиер 1780: 5]. Упоминается также [Пеплиер 1780: 11] удлинение [u:] в boue в отличие от краткого bout (boue [bu:] (грязь) \# bout [bu] («край» или «кипит»).

Правило позиционного удлинения гласной, за которой следует $e$ mиёt в языке XVII-XVIII вв., особенно важно, так как оно позволяет отличать 1) мужской род от женского в прилагательных и причастиях, заканчивающихся лю-

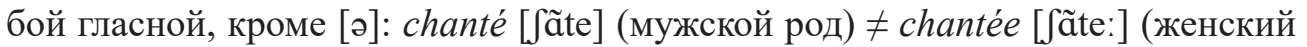
род); 2) во многих глаголах 3-е лицо единственного числа с краткой гласной от 3-го лица множественного числа с долгой гласной: rit [ri] $\neq$ rient [ri:].

К сожалению, о том, что в конечном ударяемом слоге при наличии немой конечной буквы $s$ или $x$ краткая гласная тоже автоматически превращается в долгую, не говорится ни слова, хотя это правило тоже имеет первостепенное морфологическое значение в системе того времени. В существительных и прилагательных в большинстве случаев оно позволяет различать по признаку

15 Последняя тема стала гораздо менее актуальна с появлением системы акцентов в «новой орфографии» (см. 2-ю главу «Французской грамматики»), и указания Пеплиера о $E$ [Пеплиер 1780: 4-6] предназначены помогать читателю разбираться с разными значениями буквы $e$ в массе книг, напечатанных со старой орфографией.

16 "Comme l'observation des Longues et des Brèves fait une grande partie de la régularité de la prononciation; et que presque tout le monde, et même des gens sçavants et éclairez péchent dans cette observation; les Parisien prononçant ordinairement Longues les dernières Syllabes qui sont Brèves, et les Normans, les Bretons, les Angevin, et tous les Habitants des villes situées le long de la Loire prononçant longues les pénultièmes syllabes qui sont brèves, il sera bon d'en donner des règles. " [Hindret 1687: 135]. 
долготы конечной гласной единственное число от множественного: un Grec [grek], des Grecs [gre:k]; un canard [kanar], des canards [kana:r] [Hindret 1687: 134, 136-137]. Еще в XVIII в.: «Les Ducs de Saxe [произносится как] lé Dûc de Saxe» [La Touche, Regnier-Desmarais 1730: 15].

Пеплиер также обходит молчанием грамматическую различительную роль оппозиции по признаку долготы в спряжении глаголов в subjonctif. В глаголах второй группы на ir типа finir формы «настоящего сослагательного наклонения» ${ }^{17}$ и «преходящего сослагательного» орфографически омонимичны (за исключением 3-го лица единственного числа), но они не являются омофонами. Поскольку перед ss окончаний «преходящего сослагательного» все гласные удлиняются, il faut que je finisse [finisə] (настоящее время) отличается от il fallait que je finisse [fini:sə] (преходящеe).

Второй раз в грамматике Пеплиера долгота гласных упоминается по поводу значения accent circonflexe: «Aa пишется по старому, и произносится какъ долгое $a$. А по новому одно $a$ выпускается, а вмъсто другаго становится облеченное, и такъ прежде писали jsaac, aage, baailler, а нынъ пишутъ jsâc, âge, bâillerı [Пеплиер 1780: 2]. Здесь тоже долгота гласной рассматривается больше с орфографической точки зрения, чем с фонетической. Можно было ожидать уточнения хотя бы во второй главе «О силь или удареніи словъ», но здесь тоже различие между словами по долготе гласной рассматривается только под орфографическим углом: «Различіе между удареніемъ острымъ и облеченнымъ, разумъть можно само по себъ; хотя в словахъ châsse ковчегъ и chasse, ловля; tâche cmapaнье, прилгжность и tache пятно такъ же и во многихъ другихъ словахъ оное безъ примьчанія оставлять не должно, естьли хочешь выразить оныхъ справедливое знаменованіе» [Пеплиер 1780: 19-20]. Различие между «удареніемъ острымъ и облеченнымъ» представляется как единственная возможность различить некоторые слова, но при том слово «удареніе» употребляется двусмысленно и обозначает во второй главе два совершенно разных понятия. В начале 2-й главы говорится, что «во Французскомъ языкь удареніе бываетъ только на посльднемъ и предпосльднемъ слогъ». Здесь термин ударение употребляется в своем обычном современном смысле. Но в конце главы, когда речь идет о «различіи между удареніем острымъ и облеченнымъ», слово ударение употребляется в другом смысле - прежде всего орфографическом. Может показаться, что при противопоставлении слов «с ударением облеченным» словам «с ударением острым» автор как будто подразумевает существование во французском языке двух типов ударяемых слогов с разными интонациями. Ничего подобного. На самом деле под словами «с ударением острым» следует понимать слова, в которых на ударяемом слоге нет «ударения облеченного», то есть лишенные диакритического знака, обозначающего долготу ударяемой гласной. Разумеется, не зная заранее французского, читатель Пеплиера не может правильно понять смысл процитированного места и сделать нужные выводы о существовании долгих гласных.

17 Соответственно présent и imparfait du subjonctif в терминологии Пеплиера [Пеплиер 1780: 59-119 (глава 5-я О глаголь)]. 
Более того, некоторые неточные указания могут ввести русского читателя в заблуждение. В разделе, посвященном произношению звука [ع], Пеплиер называет открытое $e$ долгим: «E ouvert открытое или долгое произносится какъ э» [Пеплиер 1780: 4], как будто выражения е открытое и долгое названия синонимичные и всякое открытое $e$ произносится как долгий звук. Но, конечно, это не так. «Открытое» и «долгое» не синонимичны. Валлар, например, четко отличает «ѐ открытое, как в словах mer, hiver, altier» от «е̂ долгое, как в словах bête, blême, poême» ${ }^{18}$. И как мы видели (см. выше chantée), бывают долгие закрытые [е] и, разумеется, бывают также краткие [ع], которые, впрочем, встречаются еще чаще, чем [ع:], как например в 3-м слоге слова

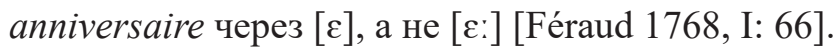

Наконец, следует подчеркнуть, что изъяснения, данные в 3-й главе грамматики Пеплиера об удвоении согласных как о признаке долготы слога, попросту ошибочны: «По старому удерживаются многія двойныя согласныя, кои не выговариваются, а только гласную дълаютъ долгою: abbé, occuper, annuler» [Пеплиер 1780: 21]. Стоит только взглянуть в словарь Феро, чтобы убедиться в необоснованности этого утверждения: «Abbé: всё кратко; occuper: всё кратко; annuler (2-й и 3-й краткие), иными словами - все кратко» ${ }^{19}$.

На самом деле удвоенная согласная буква, как правило, указывает на краткость предыдущей гласной. «Слова, которые заканчиваются двойной согласной, вслед за которой идет гласная, имеют краткий предпоследний слог Sorbonne, homme, allumette, etc.» [Hindret 1687: 14]. В некоторых случаях двойная согласная появилась вопреки этимологии, например в слове couronne, от латинского corona, как раз для обозначения краткости гласной. ${ }^{20}$ По всей видимости Пеплиер перепутал с удвоенными согласными в латыни, которые в этом языке действительно делают слог долгим.

Соответствуют ли различия тембра различиям долготы в том состоянии языка, которое описывает грамматика Пеплиера? Иными словами, существуют ли гласные звуки долгие по природе своей, как, возможно, [a:], [o:] или [ø:]?

В современном французском языке долгота может быть закреплена за определенным гласным звуком, как [a], или за некоторыми позициями под ударением, особенно перед согласными [в], [v], [3], [z], за которыми следует безударное [ə] (rêve, rose, pâte). Но, во-первых, соблюдение этой долготы не является систематическим и, во-вторых, оппозиция типа patte (лапка) [a] $\neq$

18 “L'è ouvert, comme dans mer, hiver, altier. L'ê long, comme dans bête, blême, poême" [Vallart 1744: 20].

19 'Nous n'avertissons pas toujours des brèves ; mais le silence est un avertissement en cette occasion : toutes les syllabes qui ne sont pas qualifiées longues ou douteuses, doivent être censées brèves". (Мы не всегда обозначаем краткость слогов. Но в случае молчания отсутствие помет служит указанием: все слоги, которые не отмечаются как долгие или сомнительные надо считать краткими) [Féraud 1768, I: 4; II: 203; I: 66].

20 В качестве исключений кроме предпоследних слогов всех форм imparfait du subjonctif в спряжении глаголов за исключением 3-го лица единственного числа можно процитировать, между прочим, прилагательное grosse. Заметно, что после перехода в немецкий язык прилагательное groß, große до сих пор сохранило свою долгую гласную, долгота которой утратилась во французском. 
pâte (тесто) [a:] воспринимается как оппозиция тембра между [а] и [а], в которой оппозиция по признаку долготы ([a] $\neq[a$ : ]) играет факультативную, нерелевантную роль. Кроме того, за исключением таких редких пар, как раtte (лапка) f pâte (тесто), ротте (яблоко) [॰] и раите (ладонь) [о:] фонологическая оппозиция оральных гласных по признаку тембра, за которым закреплена особая долгота, весьма слабо продуктивна. И здесь речь идет только о литературном, нормативном орфоэпическом произношении современного французского, некоторые подробности которого осваиваются сознательно носителями языка. Как при Эндрэ, ни в одном регионе Франции не соблюдаются сегодня все правила литературного произношения вместе взятые. В стандартном парижском произношении, например, где чаще всего утрачены конечные [ə], долгие звуки [a:] слова pâte или [о:] слова rose окажутся не в предпоследнем, как требовало бы строгое соблюдение правил орфоэпии, а в последнем слоге. А в речи большинства носителей французского, родившихся южнее Луары, наоборот, сохраняется конечное заударное [ə], но [a:] и [o:] произносятся одинаково как [a] и [р]. Парижанин произносит [во:z], южанин — ['вәzə], но литературная норма требует ['во:zə].

Фонологическая оппозиция долготы утратилась еще раньше для гласных, находящихся в конечной ударяемой позиции и различавшихся только по признаку долготы, без ощутимого изменения тембра, — [y:] и [у], [i:] и [i]. Напр. $m u r$ (стена) и $m \hat{u} r$ (зрелый). Последние черты таких оппозиций по долготе без различия тембра фиксируются в конце XIX в. (см. [Michaëlis, Passy 1897]).

Итак, если учесть долготу, современная ситуация такая: звуки [a], [ø] долгие. Звук [o:] может быть долгим под ударением (beau [bo:]); [a], [0], как правило, краткие. [œ] чаще всего краткий, но может быть позиционно долгим [bœ(:)в(ә)]. Звуки [i], [u], [y] могут быть позиционно долгими (île, voûte, mûre).

Как обстояло дело в XVIII веке?

Лишь Шифле настаивает на большой разнице, существующей между долгим и кратким $a$. По мнению Шифле, у тех, кто не умеет отличать краткое $a$ от $a$ долгого, очень плохое произношение. В поэзии он считает рифму краткого $a$ с долгим грубой ошибкой, а в быту она может привести к смешным недоразумениям ${ }^{21}$. Такая ошибка «весьма заметна», — пишет Шифле. Но идет ли речь о разнице в тембре помимо разницы в долготе? «Весьма заметной» разница может быть и только потому, что французский слух XVII в. еще очень четко воспринимает долготу. Из этого необязательно вытекает, что по тембру краткое [a] отличается от долго [a]. Что же касается гласной $o$, то Шифле эксплицитно упоминает лишь разницу между кратким и долгим $o$, но он молчит о тембре: «O произносится как в латыни. В некоторых словах оно долгое. В других оно краткое» [Chiflet 1659: 186].

${ }_{21}$ "Ce qui reste difficile en la prononciation de l' $a$, et en quoy les Grammairiens sont defectueux, c'est de discerner le brief du long: autrement leur mauvaise prononciation sonneroit tres-mal, et seroit fort reconnaissable. C'est pourquoy en poësie ce seroit une faute de faire rimer, blâme avec dame, ou sage avec imâge: et en langage familier, ce defaut feroit de mauvais equivoques. Par exemple, qui diroit, faisant l'a de page brief: J'ay veu et consideré trois pages de Monsieur Coeffeteau" [Chiflet 1659: 174]. 
Показательно, что в обоих учебниках Жийе-Веделена, «Nouvelle manière d'écrire comme on parle en France» (1713) и «Instructions cretiennes mises en ortografe naturelle: pour faciliter au peuple la lecture de la sience du salut» (1715), не отражается никакого различия по тембру между долгими и краткими гласными. Автор ставит себе двойную цель - выдумать алфавит и правописание, которые отражают как можно вернее и как можно проще произношение простого народа. Но при всем своем желании сделать издание молитвенника как можно доступнее, Жийе-Веделен считает нужным ввести диакритические знаки для обозначения долготы. Зато он не выдумывает других букв для обозначения самих долгих гласных. В конце правления Людовика XIV еще нет достоверного следа изменения тембра при произношении долгой гласной.

В 1730 г. между о и $\hat{o}$ Ла Туш не называет никакой разницы, кроме долготы: «Немцы придают букве $\hat{o}$ с циркумфлексом звук женского $e$; но во французском языке циркумфлекс лишь делает $о$ более долгим» ${ }^{22}$. Однако именно у Ла Туша встречается первый намек на возможное наличие разницы по тембру

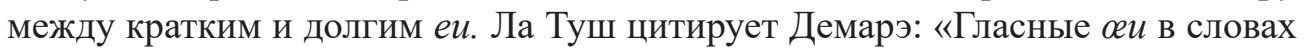
bøuf, øuf, chœur, сœur, sœur произносятся как в словах feu и јеu», - утверждает Демарэ. И Ла Туш комментирует: «Эти два типа слов произносятся с большой разницей. Первые, написанные через $\propto$, звучат очень ясно, как буквы eur в словах peur и bonheur. А другие с еи имеют темный звук» ${ }^{23}$. Вот первые следы разницы в тембре между [œ] и [ø].

Более достоверные указания о влиянии долготы или краткости гласной на ее тембр появляются только в течение XVIII в., и в 1772 г. в 6-м издании Вайи уже читаем: «Кроме того, если различаем тяжелое (низкое) $\hat{a}$ в pâte (...) от того $a$, которое встречается в patte, лапка животного; темное закрытое $e$ слов nez, pied, sauter, châtier от ясного закрытого е слов né, épié, sauté, châtié; тяжелое $i$ в gite от острого $i$ в petite; тяжелое (низкое) $\hat{u}$ в flute от острого $u$ в butte; тяжелое (низкое) eй в јейе от острого еи в јеune homme; и, наконец, если различаем тяжелое (низкое) oй в voûter от краткого ou в vouloir, то получается 21 гласная или 21 простой звук» ${ }^{24}$. О существовании двух $o-$ [0] и [o] - не упоминается, но свидетельство Вайи доказывает, что в последние тридцать лет XVIII в. уже существует разница между [а] и [a:], между [œ] и [ø:], и что реализации [i] и [i:], [u] и [u:], [y] и [y:] отличаются не только по признаку долготы, но и по тембру: долгие произносятся «ниже», чем краткие. Но, видимо, разница между [i] и [i:], [u] и [u:], [у] и [у: менее чувствительна, и поэтому она исчезнет раньше.

22 “Les Alemans donnent à l'ô marqué d'un circonflexe le son d'un $e$ féminin ; mais cet accent ne sert en François qu'à rendre l'o plus long” [La Touche, Desmarais 1730: 10].

23 Курсив наш. "Mr. Desmarais: Les voyelles œ, dans bœuf, œuf, chœur, cœur, sœur, se prononcent comme dans feu et jeu. Ces deux sortes de mots se prononcent fort diféremment. Les premiers en $\alpha$, qui ont le son fort clair, comme les lettres eur dans peur, bonheur; au lieu que les autres en eu ont le son obscur" [La Touche, Desmarais 1730: Avertissement].

24 "Si outre cela on distingue l'â grave de pâte (...), de celui qui est dans patte d'un animal ; l'é fermé sombre des mots, nez, pied, sauter, châtier, de l'é fermé clair des mots, né, épié, sauté, châtié; l'î grave de gîte, de l'i aigu de petite; l'âu grave de flute de l'u aigu de butte, l'ê̂ grave de jeune (sic) de l'eu aigu de jeune homme; et enfin l'ô̂ grave de voûter, de l'ou bref de vouloir; on pourra compter vingt et une voyelles, ou vingt et un sons simples" [Wailly 1772: 197]. 
Из свидетельства Вайи вытекает, что тот период, язык которого описывается в русском переводе грамматики Пеплиера, является в самом деле переходным в истории фонетики гласных: уже отмечается взаимосвязь между долготой и тембром гласной. Некоторые изменения уже закрепились, и картина уже близка к современной, когда остались различия тембра, связанные с долготой, но почти полностью утратились оппозиции по этому последнему признаку.

Тем не менее, эти важные изменения не нашли никакого отражения ни в немецкой версии, ни в русском переводе грамматики Пеплиера. Отсутствие обсуждения вопроса о долготе гласных и указаний на существование разных видов «а» или «еu» в зависимости от долготы - главный недостаток «Французской грамматики». Опираясь только на нее, русский читатель составит себе глубоко искаженное представление о вокализме и просодии французского языка последней четверти XVIII в..

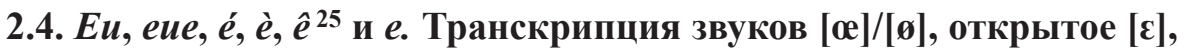 закрытое [е] и безгласное $e$ [ә] \\ - $[\propto] /[\varnothing]$}

Французские оральные гласные звуки [ə], [œ], [ø] и [у] не имеют себе подобных в русском языке, и поэтому изображение их русскими буквами особенно затруднительно. Французский звук [y] Сокольский передает приблизительно, посредством буквы ю, как до сих пор принято во многих учебниках. Звук, обычно обозначаемый буквами еи, еие, то есть [œ] или [ø] ${ }^{26}$, переводчик изображает посредством условного сочетания букв $\hat{\imath} е$, в котором $\hat{\imath} o$ (с надстрочным знаком, стоящим между обеими буквами) - эквивалент современного ё. Но, как было отмечено, Сокольский прагматично уточняет в сноске, что «произношеніе еи учиться должно изустно» [Пеплиер 1780: 7] ${ }^{27}$. Действительно, если не учесть условность транскрипции, читатель истолкует нечто вроде [ијо(j)э], которое «однимъ слогомъ произнести должно». С французскими $[\propto] /[\varnothing]$ такой звук имеет мало общего, но в самом деле это лучшее, что русская фонетика и кириллица позволяют выдумать для неточного изображения этого чужого звука. Но такие звуки, как [ә], [œ], [ø] и [у], существуют в немецком, и они изображаются очень просто как $e$, ӧ и $\ddot{u}$. Нельзя не задаться вопросом, почему же в переводе с немецкого Сокольский не приводил, помимо собственной транскрипции, обозначение звука из немецкого издания для тех, кто уже говорит по-немецки? Он же знал, что многие его читатели уже учили немецкий. А для русских читателей, владеющих немецким, сравнение с немецкими $\ddot{o}$ и $\ddot{u}$, которые произносятся как по-французски, решило бы вопрос о транскрипции этих звуков.

25 Обозначаемый буквой $\hat{e}$ звук отличается от [ع] только своей долготой - он бывает всегда долгий. Поскольку транскрипции Сокольского, как правило, не отражают долготу, мы не изучаем отдельно транскрипцию долгого и краткого открытого [ع].

26 О гипотезе относительно существования во второй половине XVIII в. двух различных звуков, отличающихся друг от друга не только по долготе, но и по тембру, см. выше.

27 В немецкой версии этого замечания здесь нет. Оно не нужно ввиду наличия в немецком описываемого звука и буквы $\ddot{~ д л я ~ о б о з н а ч е н и я ~ е г о . ~}$ 


\section{- $[\mathrm{e}] /[\varepsilon]$}

Выбор Сокольского передать открытое [ع] через э и закрытое [е] через $e$ может удивить, так как в русском языке э, употребляемое для обозначения /э/ после паузы, после гласной или твердой согласной, произносится открыто только в тех случаях, когда за /э/ не следует согласная, произносимая мягко (неважно, мягкая ли последняя фонологически или просто фонетически). Можно было объяснить оппозицию $[\varepsilon] \neq[\mathrm{e}]$ через оппозицию между открытым [ع] словоформы этот и закрытым [е] форм множественного числа эти, этих и т. д. Правда, в XVIII в. местоимение этот еще только проникало в письменный литературный язык. Но если хотелось передать разницу между $[\varepsilon]$ и [e], употребляя по одной букве русского алфавита, почему Сокольский не подумал о букве $r$ ? Ять совсем не употребляется в его транскрипциях. Но в конце XVIII в. хотя бы в «высоком стиле» $е$ и $ъ$ еще отличались как раз по признаку открытости/закрытости [Панов 2002: 338-360]. Переводчику стоило только подчеркнуть, что при транскрипции через $e$ и $ъ$ не обозначается никакого смягчения предыдущей согласной во французском слове. Но «во второй половине XVIII в. продолжалось угасание < $>$ > как фонемы», пишет М. В. Панов [2002: 359]. Возможно, в 1770-1780 гг. разница между закрытым г и более открытым е уже была такой шаткой, что Сокольский побоялся, что она будет непонятна читателю. Но выбор передачи оппозиции через $e$ и э не более удачен, тем более что Сокольский не придерживается его последовательно. В приведенных таблицах встречается много случаев, в которых французский [ع] транскрибируется, как будто на его месте стоит [е] (perdrions, пердріонъ; destin дестейнъ). Кроме того, е также употребляется иногда для передачи [ә]. В транскрипции [cmerjõ:] aimerions через емерьіонъ Сокольский два раза употребляет букву $е$, и два раза употребляет ее ошибочно, не по значению, которое он сам ей придал: в «емерьіонъ» $е$ стоит сначала для обозначения [ع], а потом для транскрипции [ə]. В aimerions нет ни одного закрытого [е].

\section{- [ə]}

Передача звука [ə], существующего в немецком языке, составляет для Сокольского непреодолимую трудность, хотя на самом деле благодаря московскому аканью дать представление о [ә] несложно, стоит только указать на $o$ или $а$ после твердой согласной в заударном слоге.

Немногочисленны исходные ошибки, когда еще до транскрипции французское [е] или [ع] принимается за [ә], то есть неверно истолковывается транскрибируемый гласный. Но такие ошибки есть: слову sérieux [serjø:] эксплицитно приписывается [ə], но Сокольский пишет сері̂о [Пеплиер 1780: 5], и благодаря непоследовательности его транскрипции, в которой $е$ также и даже в первую очередь «официально» обозначает [е], ошибка не отражается в русском фонетическом изображении слова переводчиком «Французской грамматики».

Не выдумав для [ә] особого условного знака, Сокольский передает его без последовательности и постоянно колеблется между е (емерьіонъ aimerions, гобеле gobelet, парлере parlerai) внутри слова и нулевой транскрипцией, как 
внутри слова (епронъ для [ерәг̃̃] éperon), так и с большей последовательностью в конце слов, где в первом издании еще сохраняется твердый знак (affreuse афрі̂езъ). Решение не транскрибировать конечное безударное [ə] нарушает орфоэпию французского литературного произношения высокого стиля. Но правда, что в быту допускается пренебрегать безударным [ә] ${ }^{28}$.

Заметим, что после конечного $l$ Сокольский транскрибирует [ә] через ль (парль [parlə] parlent), что и приводит к невозможности отличить конечный [1] от конечного $[K]$ (см. ниже о $[\Lambda]$ ). Кроме того, по непонятной причине после конечного [n] Сокольский чаще всего транскрибирует [пә] через ень: une mort affreuse [уnə мэр afrœ:zə] ень мор афріิозъ. Все слова, заканчивающиеся на eine, так же странно транскрибируются через ень (реіпе [рв:пә] пень). Этот выбор приводит к ряду неточностей:

1) если в транскрипции слов на еine употребляется $е$ вместо э, читатель может ошибочно подумать, что по-французски ei произносится как [е], а не как $[\varepsilon]$, тем более, что в «пень» за $e$ как будто идет мягкий [н'], а в русском мягкость следующей согласной исключает реализацию /э/;

2) невозможно отличить слова, заканчивающиеся на [в:nə], от слов, кото-

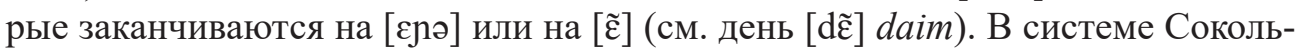
ского нельзя различить французские слова peine [рє:пә] (печаль) и peigne [рєлә] (расческа). Их оба приходится транскрибировать как «пень», а читатель перевода Сокольского все равно сможет прочитать [п'ен'].

Кроме того, в случае ошибочных транскрипций других носовых, путаница распространяется также на слова на [о̃] и даже на слова на [уnә] (см. выше транскрипцию ипе [уnә] mort affreuse через ень или finir un discours [finir œ̃ disku:r] фини рень дискур, также через ень» [Пеплиер 1780: 18; 17]. Наконец, отметим, что последовательное употребление редкой буквы э вместо $e$ в тех местах, где графема э как раз и требовалась по сформулированным самим Сокольским правилам, берегло бы глаз русского читателя при столкновении с такими транскрипциями, как день или пень. Более «экзотичные» дэнь и пэнь послужили бы сигналом и удержали бы читателя от чтения по привычке этих транскрипций как русских слов день и пень.

Итак, из-за непоследовательности в соблюдении собственных правил транскрипции Сокольский предлагает русскому читателю большое количество двусмысленных чтений. Некоторые буквы или сочетания букв, выбранные для транскрипции [е], [ع] и [ə], имеют по два или больше значений:

\begin{tabular}{|c|c|c|c|c|c|c|c|c|c|c|c|c|}
\hline \multirow{2}{*}{\multicolumn{3}{|c|}{$\begin{array}{c}\text { Внутри слова } \\
\mathrm{e}\end{array}$}} & \multicolumn{10}{|c|}{ В конце слова } \\
\hline & & & \multicolumn{5}{|c|}{-ень } & \multicolumn{2}{|c|}{-онъ } & \multicolumn{3}{|c|}{-ль } \\
\hline [e] & [ə] & {$[\varepsilon]$} & {$[\varepsilon(:) n ə]$} & [عрә] & {$[\tilde{\varepsilon}]$} & {$[\tilde{\propto}]$} & [yno] & [эnə] & {$[\tilde{\jmath}]$} & [lə] & [1] & {$[K]$} \\
\hline
\end{tabular}

28 См. систему транскрипции, употребляемую в [Gillet-Vaudelin 1713; 1715]. 


\section{5. Дифтонг oi, oie. Старый [wع] или новый [wa]?}

Дифтонг оі во «Французской грамматике»

\begin{tabular}{|c|l|l|l|l|}
\hline \multicolumn{1}{|c|}{$[\mathbf{w a ]} /[\mathbf{w \varepsilon}]$} & $\mathbf{y a}$ & $\begin{array}{l}\boldsymbol{O} \boldsymbol{i} \text {, оу выговариваются въ } \\
\text { односложныхъ, какъ } y a\end{array}$ & оä & $\boldsymbol{O} \boldsymbol{i}, \boldsymbol{o y}$, wie ö̈ in einer Sylbe \\
\hline $\begin{array}{c}{[\text { nwer] } /[\text { nwar }]} \\
\text { noir }\end{array}$ & нуар & noär \\
\hline
\end{tabular}

Если французских грамматиков XVIII в. разделить на «древних» и «новых», то лучшим критерием послужит их отношение к произношению дифтонга, обозначаемого буквами oi: [wع] или все-таки [wa]? Как известно, именно второй вариант станет общепринятой нормой с начала XIX в., но изменение это касается только орального дифтонга. Его носовой вариант оin до

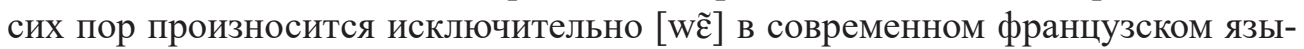

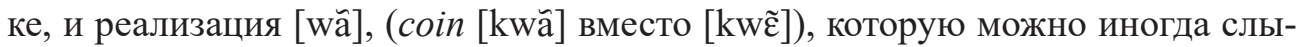
шать в некоторых регионах ${ }^{29}$, преимущественно в речи представителей старшего поколения, остается далеко за пределами литературной нормы.

У произношения дифтонга oi долгая история. Условной датой победы [wa] над [wع] обычно считают Французскую революцию: произношение парижского народа через [wa] восторжествовало над консервативным придворным произношением через [wع]. Однако в подробностях не все так просто. Было бы так же ошибочно считать, что [wa] было совсем неупотребительно в просвещенных кругах в течение XVIII в., как думать, что [we] совсем вымерло с революцией. Как напоминает Л. Пак [Pasques 1975: 68-69], произношение [wa] уже засвидетельствовано в XIV в. в Registre du Parlouer aus borjois в такой словоформе, как courtoisie, написанной cortoasie. С другой стороны, еще в 1834 г. Н. Ланде пишет в Dictionnaire général et grammatical des dictionnaires français «Мы не разделяем мнения тех, кто утверждает, что дифтонг оi всегда должен звучать как oa: foisonner, loi, royal однозначно не произносятся foazoné, loa, roaial, а на самом деле foèzoné, loè, roèial» ${ }^{30}$.

На рубеже XVII-XVIII вв. Эндрэ, вслед за всеми предшественниками [Oudin 1632; Chiflet 1659], описывает oi как [wع]. Он, правда, не обходит молчанием существование простонародного произношения [wa], но он исключает его из нормы, цитируя [wa] в длинном списке самых распространенных ошибок в произношении, составленном им в начале учебника. «Несколько человек, как при Дворе, так и в Париже, говорят du boüas, des noüas, troüas, moӥas, des poüas, voüar вместо du bois, des noix, trois, mois, des pois, voir, хотя произношение этих слов не труднее, чем произношение слов fois, Rois, voix, choix, crois, loix, des droits, pouvoir, devoir и других слов, в которых дифтонг oi

29 Вариант, достаточно часто слышанный автором данной работы лет двадцать назад в гасконской деревне в окрестностях Тулузы.

30 "Nous ne sommes point du goût de ceux qui prétendent que oi diphtongue doit toujours sonner oa: foisonner, loi, royal ne se prononcent certainement pas foazoné, loa, roaial; mais bien foèzoné, loe, roèial" [Landais 1834 по Pasques 1975: 69]. 
произносится как oüais» ${ }^{31}$. Понятно, что Эндрэ пишет для бургундского герцога, и, безусловно, он один из представителей «древних» среди грамматиков.

Несколько лет спустя Мийеран описывает oi по-другому: «[oi, oy] coxpaняют естественное свое произношение в односложных и других словах и произносятся как иа у немцев» ${ }^{32}$.

Но зато Бюффье в 1709 г. признает только [wع], когда oi произносится как

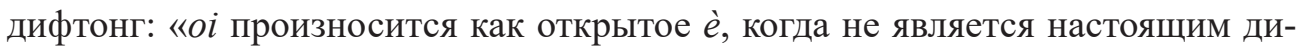
фтонгом. Но часто o и $i$ составляют настоящий дифтонг, в котором оба звука $o$ и е произносятся в одном слоге. (...) Еще сто лет тому назад во всех случаях, когда писали oi в одном слоге, произносили также оѐ» ${ }^{33}$. Бюффье категорически осуждает произношение дифтонга oi как [wa]: «Надо избегать другого произношения, которое часто встречается даже среди образованных людей в Париже, но дефектность которого признается всеми, — когда произносят bois, poix и т. д., как будто написано bouas, pouas, вместо того чтобы произносить boès, poès» ${ }^{34}$.

Как раньше Эндре, Бюффье приводит список тех случаев, в которых $о i$ обозначает не дифтонг, а простой звук - чаще всего [ع]. Но в редких случаях - в первом лице единственного числа будущего времени и «прошедшего простого» oi имеет звук [е]. Произношение $o i$ как простого гласного звука [ $\varepsilon$ ] встречается в некоторых широко употребительных словах и окончаниях. Список, приводимый Эндрэ и Бюффье, встречается почти в каждом нормативном труде о произношении и повторяется почти без изменения вплоть до конца XVIII в. (см. [Hindret 1687: 59, 61, 63; La Touche, Regnier Desmarais 1730: 5051; Vallart 1744: 27; Féraud 1768: 26-27; Wailly 1772: x] $]^{35}$ ).

Современному носителю французского несложно запомнить, в каких именно словах oi читалось не как дифтонг, а как простой гласный звук $[\varepsilon]$ или же как [е] - в глагольных окончаниях на oi без конечного $s$. В список исключений входят все словоформы, в которых под влиянием Вольтера oi, ois были заменены в правописании на ai, ais (chanterai [e], chantai [e], chanterais $[\varepsilon]$,

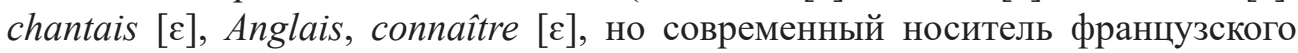
знает, что в Danois слышалось [wع], так как еще в современном французском слышится здесь дифтонг, а не простой звук. Исключения из этого диахронического правила немногочисленны: некоторые слова, в которых дифтонг переходил в простой звук $[\varepsilon]$, снова перешли в дифтонг под влиянием правописа-

31 “Combien en voyons-nous par exemple à la Cour aussi bien qu'à Paris qui disent du boüas, des noüas, troüas, moüas, des poüas, voüar pour dire du bois, des noix, trois, mois, des pois, voir, dont la prononciation ne nous est pas plus difficile que celle de fois, Rois, voix, choix, crois, loix, des droits, pouvoir, devoir, et d'autres mots où la diphtongue oi se prononce comme oüai" [Hindret 1687: 7].

32 "Elles retiennent leur prononciation naturelle dans les monosyllabes, et autres, et se prononcent comme l'ua des Alemans" [Milleran 1694, I: 137].

33 “Oi diphtongue impropre se prononce en è ouvert : mais souvent oi est une diphtongue propre, qui désigne les deux sons de l'o et de l'è dans un seul temps de silabe (...) Il n'a pas cent ans que par tout où l'on écrivoit oi dans une silabe, on prononçoit aussi oè" [Buffier 1709: 365-363].

34 'Il faut éviter une prononciation vicieuse de l'oi qui est commune même parmi d'honnêtes gens à Paris, mais que tout le monde avoue être vicieuse : c'est de prononcer bois, pois, etc. comme s'il y avoit bouas, pouas, au lieu de prononcer boès, poès" [Buffier 1709: 366-367].

35 Wailly цитируется по изданию 1772 года, но первое издание датируется 1754 годом. 


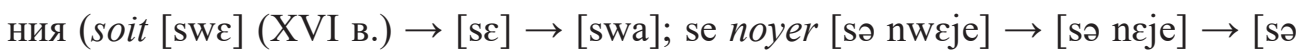
nwaje]; il croit [i krwe] $\rightarrow$ il croit [i kre] $\rightarrow$ il [il krwa] и др.). Цитируя Вожла и

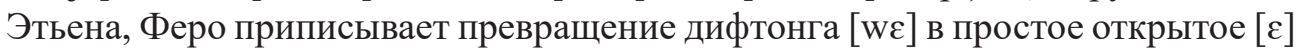
в этих словах влиянию итальянцев при дворе Екатерины Медичи. В конце XVI в. произношение дифтонга вместо [ع] в широко употребительных словах стало восприниматься как педантство [Féraud 1768, II: 208].

Во «Французской грамматике» тоже приводится список исключений, в которых oi звучит не как дифтонг, а как простой звук. Но не различаются те, которые содержат [ع], и те, которые содержат [е]. «Во всьхъ такихъ словахъ выговаривается как е», то есть как [е] по системе Сокольского, хотя на самом деле за исключением глагольных окончаний будущего и passé simple звучит [ع], а не [е] [Пеплиер 1780: 11].

Поскольку Жийе-Воделен, один из самых дерзких «новых», в своих учебниках для распространения благочестия в народе старается как можно вернее передавать народное произношение, от него можно было ожидать транскрипции [wa] вместо [wع]. Но в обеих своих книгах [Gillet-Vaudelin 1713; 1715] он передает дифтонг oi буквой $о$ и особым выдуманным знаком - $a$ с круглым хвостиком, который обозначает в его книгах открытое $[\varepsilon]^{36}$. Итак, даже согласно Жийе-Воделену, оi прозносится либо как простой звук [ع] или [е], либо как [we]. Видимо, в последние годы правления Людовика XIV [wa] еще не является общепринятым произношением даже в парижском простонародье.

И в самом деле, еще в 1730 г. в труде Ла Туша указывается только произношение oi как [wع]: «В односложных словах Roi, loi, moi, bois, je dois, droit [jus] etc. произносите [wع]» ${ }^{37}$. И в 1744 г. Валлар подтверждает, что oi как простой звук или « diphtongue oculaire » (когда это не настоящий дифтонг, а лишь «дифтонг только для глаза») произносится как [ع] или [е], но когда oi обозначает настоящий дифтонг, то оi произносится «как оѐ», т. е. [wع]: «оѐ. oi. oiseau, moine, reçois, toi, etc. oè. eoi. cheoir, seoir, asseoir, bourgeois» [Vallart 1744: 24-25].

На фоне общепризнанности [wع] появление грамматического словаря Феро в 1761 г. можно считать вехой в истории дифтонга oi: реализация [wa] впервые приводится как единственный вариант в фундаментальном нормативном труде о литературном языке. Феро был иезуитом, и, вследствие решения Людовика XV запретить орден во Франции, первое издание словаря ученого священника было опубликовано не во Франции, а в Авиньоне, принадлежавшем тогда папе римскому. Кроме того, сам Феро был уроженцем Марселя и долго работал над трактатом о провансальском языке, который ему не удалось завершить. Это значит, что Феро владел провансальским. Но вряд ли мы можем усмотреть диалектное влияние в смелости выбора Феро. Все творчество ученого свидетельствует о его усилиях для фиксирования лучшего узуса литературного языка. Но отдаленность от двора могла сыграть позитивную роль, освободив Феро от предрассудков против нового произношения, и он

36 avoar avoir [Gillet-Vaudelin 1715: 23].

37 "Dans les monosyllabes: Roi, loi, moi, bois, je dois, droit [jus], etc. prononcez Roè, loè, etc." [La Touche 1730: 54]. 
мог объективно констатировать переход от [wع] к [wa] в литературном языке. Стоит подчеркнуть, что статья oi занимает у Феро целых шесть страниц, на которых автор обсуждает его произношение, вопросы правописания, рифмы на oi. Замечательно, что при обсуждении вопроса об исключениях, в которых $o i$ читается как è ouvert, Феро противопоставляет $\grave{e}$ звуку $о a$, даже когда он цитирует авторов, которые знают только $[w \varepsilon]$ и $[\varepsilon]$. Итак, у Феро нет и следа традиционного [wع]. По всей видимости, провансалец спокойно принимает закрепление [wa] как уже совершившийся факт.

Правда, голос «древних» еще прозвучит. В 1772 г. в 6-м издании своего учебника Вайи возвращается к [we]: «В других словах (то есть в тех, в которых не слышится просто [ $\varepsilon]$ ) oi и oie составляют дифтонг и произносятся как

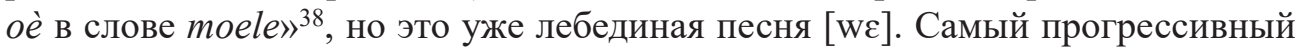
из «новых», Домерг, который резко выступает против замены $[K]$ на [j], описывает $o i$ как oa и сокращает список слов, в которых дифтонг должен произноситься как $[\varepsilon]$. Во всех словах, в которых восстанавливается настоящий дифтонг (croire, croître, froid...), восстанавливается именно [wa] [Domergue 1778: 48].

Подводя итоги, можно сказать, что переход от [we] к [wa] в литературном языке завершился где-то в 1750-1760 гг. Безусловно, [wع] имел своих сторонников до конца века, но [wa] вошел в литературную речь, в которой старая норма сохранялась сознательно, против течения.

Вернемся к грамматике Пеплиера. Какой вариант предлагается русскому читателю ее переводчиком? Как было отмечено, перевод Сокольского фонетической части грамматики очень верен оригиналу. Но в описании произношения $o i$ читателя русского перевода ожидает сюрприз. Немецкая версия транскрибирует oi как ӧ̈, то есть о + a с Umlaut [Pepliers 1749: 8; 1756: 8]. Сочетание ӧ̈ однозначно указывает на произношение [wع]. Зато в обоих изданиях перевода Сокольского oi транскрибируется не как $y$ э, а именно как $y a$. Правда, в типографии того времени обозначение немецкого Umlaut в шрифтах типа «Fraktur» менее заметно, чем современные две точки. Вместо них употребляется знак в виде надстрочной запятой или густого придыхания. Трудно поверить, что Сокольский просто пренебрег обозначением Umlaut при переводе, хотя надо признать, что именно этот раздел содержит грубую ошибку перевода. Немецкое «Oi, oy, wie ö̈ in einer Sylbe» Сокольский неправильно понял, переведя как «Oi, оу выговариваются въ односложныхъ, какъ $y a »$. Разумеется, немецкий оригинал не значит, что $o i, o y$ читается ö̈ только в односложных словах. В немецком оригинале имелось в виду, что oi выговаривается как звуки ӧ̈, произносимые одним слогом.

Передача Сокольским французского о $i$ при помощи уа слишком последовательна, чтобы можно было допустить, что Сокольский просто ошибся, не заметив при чтении Umlaut и заменив все $a$ с Umlaut на простые $a$. В этот единственный раз Сокольский сознательно отдаляется от оригинала и решительно выбирает лагерь «новых», оставляя немецкую версию грамматики Пеплиера в

38 "Dans d'autres mots oi et oie forment une diphtongue, et se prononcent comme ò̀ de moele" [Wally 1772: x]. 
лагере «древних». Впрочем, выбирая вариант [wa], уловив либо из новых французских книг, как словарь Феро, либо из живого общения с интеллигентными носителями языка важное изменение, переводчик поступает целесообразно. Как было показано в работах С. Власова, Х. Ржеуцкого или Л. Московкина об обучении французскому и французской грамматике в России [Власов, Московкин 2014; Rjéoutski, Vlassov 2013], цель этого обучения очень прагматична. Воспитываются не лингвисты, а люди, которые будут говорить на французском языке в практических целях. Нет сомнения, что русскому читателю Сокольский старался дать представление о самом современном состоянии живого французского языка. Другой вопрос, в какой мере ему это удалось.

\section{3. Носовые гласные}

3.1. Список французских носовых гласных звуков, транскрибированных русскими и немецкими буквами в грамматике Пеплиера ${ }^{39}$

Таблица 3

Обозначение носовых гласных звуков во «Французской грамматике»

\begin{tabular}{|c|c|c|c|c|}
\hline 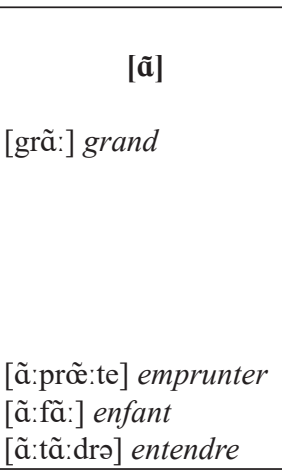 & ан & 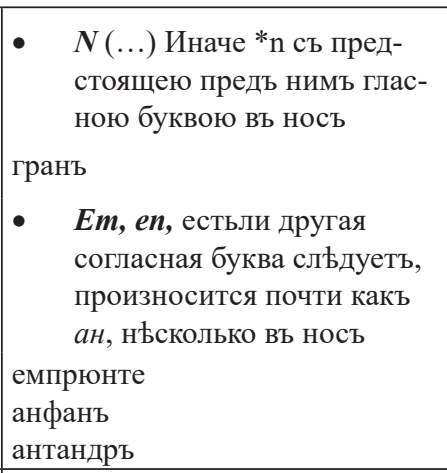 & ang & $\begin{array}{l}\text { Sonst wird das } * N \text {, mit } \\
\text { seinem vorhergehenden } \\
\text { Vocal etwas durch die } \\
\text { Nase ausgesprochen } \\
\text { grang } \\
\text { Em, en, wenn ein andrer } \\
\text { Consonans darauf folget, } \\
\text { fast wie ang, ein wenig } \\
\text { durch die Nase } \\
\text { angprünteh } \\
\text { angfang } \\
\text { angtander } \\
\end{array}$ \\
\hline $\begin{array}{l}\quad[\mathbf{i} \mathbf{a}] /[\mathbf{j a} \mathbf{a}] \\
{[\text { oriã }]} \\
{[\text { pasjã }]^{39}}\end{array}$ & іан & $\begin{array}{l}\text { Orient, patient произносятся } \\
\text { оріанъ } \\
\text { пасіанъ (без пометы «в носъ») }\end{array}$ & iang & $\begin{array}{l}\text { Orient, patient, machen } \\
\text { drey Sylben } \\
\text { oriang } \\
\text { paßiang }\end{array}$ \\
\hline $\begin{array}{l}\quad[\tilde{\varepsilon}] \\
{[\mathrm{d} \tilde{\varepsilon}] \text { daim }} \\
{[\tilde{\tilde{\varepsilon}}] \text { faim }} \\
{[\mathrm{m} \tilde{\varepsilon}] \text { main }}\end{array}$ & !ейнь & 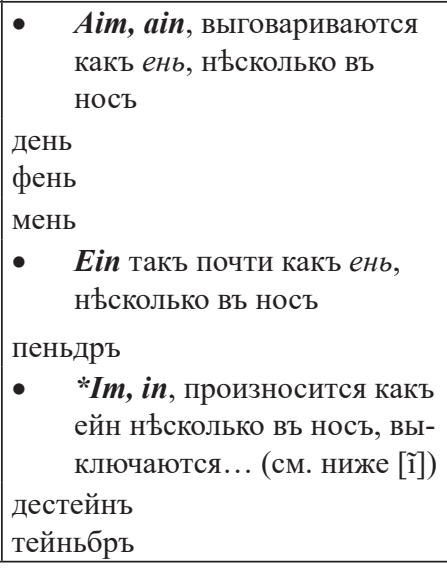 & $\begin{array}{l}\text { eing } \\
\text { eng }\end{array}$ & $\begin{array}{l}\text { Aim, ain, fast wie eing } \\
\text { oder eng, etwas durch die } \\
\text { Nase } \\
\text { deng } \\
\text { feng } \\
\text { meng } \\
\text { Ein fast wie äng, etwas } \\
\text { durch die Nase } \\
\text { pängdre } \\
\text { *Im, in, fast wie eing, } \\
\text { etwas durch die Nase. } \\
\text { desteing } \\
\text { teingbre }\end{array}$ \\
\hline
\end{tabular}

39 [Féraud 1768] отличает «ра-сіan» в двух слогах через [j] от orient «ori-an» в трех слогах с [i]. 


\begin{tabular}{|c|c|c|c|c|}
\hline 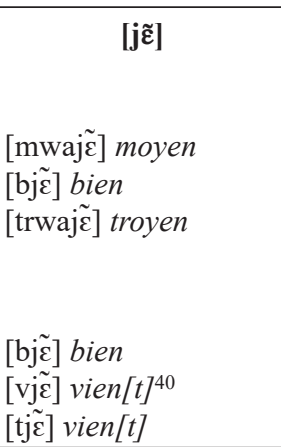 & $\begin{array}{l}\text { ьіен } \\
\text { !ьен }\end{array}$ & $\begin{array}{l}\text { • } \quad \text { Слова, въ коихъ е, i, у, } \\
\quad \text { предъ еп стоя́тъ, } \\
\text { произносятся какъ ень } \\
\text { [нет транскрипции] } \\
\text { [нет транскрипции] } \\
\text { [нет транскрипции] } \\
\bullet \quad \text { Ien произносится іен въ } \\
\quad \text { носъ. } \\
\text { бьенъ } \\
\text { вьіенъ } \\
\text { тьенъ }\end{array}$ & jeng & $\begin{array}{l}\text { Ien fast wie jeng, etwas } \\
\text { durch die Nase } \\
\text { bjeng } \\
\text { wjeng } \\
\text { tjeng }\end{array}$ \\
\hline $\begin{array}{l}\text { [ĩ] } \\
\text { [ĩ:by] imbu } \\
\text { [ĩ:dcks] index }\end{array}$ & - & $\begin{array}{l}\text { Выключаются слова } \\
\text { начинающіяся съ } i m, \text { или in } \\
\text { имбю } \\
\text { индексъ }\end{array}$ & - & $\begin{array}{l}\text { Nimm aus die Wörter, } \\
\text { welche von im oder in } \\
\text { anfangen } \\
\text { imbü } \\
\text { index }\end{array}$ \\
\hline $\begin{array}{c}\text { [̃̃] } \\
\text { [epərõ] éperon }\end{array}$ & OH & $\begin{array}{l}N(\ldots) \text { Иначе *n съ } \\
\text { предстоящею предъ нимъ } \\
\text { гласною буквою въ носъ } \\
\text { епронъ }\end{array}$ & ong & $\begin{array}{l}\text { Sonst wird das } * \boldsymbol{N}, \text { mit } \\
\text { seinem vorhergehenden } \\
\text { Vocal etwas durch die } \\
\text { Nase ausgesprochen } \\
\text { eprong }\end{array}$ \\
\hline $\begin{array}{l}{[\varepsilon m j \tilde{s}:] \text { aimions }} \\
{[\varepsilon m e r j \tilde{j}:] \text { aimerions }}\end{array}$ & bîoH & $\begin{array}{l}\boldsymbol{I o}, \text { произносится какъ } \hat{\imath} \text { въ } \\
\text { окончаніи спряженій, естьли } \\
\text { напереди не стоя́тъ двъ } \\
\text { согласныя буквы: } \\
\text { емьіонъ } \\
\text { емерьіонъ } \\
\end{array}$ & jong & $\begin{array}{l}\text { Io, wie } j o, \text { in den Termi- } \\
\text { nationibus conjugatio- } \\
\text { num, wenn nicht zwey } \\
\text { Consonantes vorhergehen } \\
\text { ämjong } \\
\text { ämerjong } \\
\end{array}$ \\
\hline 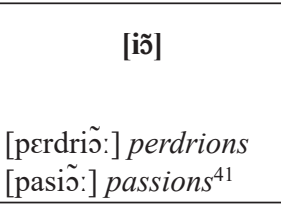 & іон & \begin{tabular}{|l|} 
[Io] естьлижъ будутъ двЂ \\
согласныя, то дЂлаетъ оно два \\
слога \\
пердріонъ \\
пассіонъ \\
\end{tabular} & iong & $\begin{array}{l}\text { Sonst macht [Io] zwey } \\
\text { Sylben aus } \\
\text { perdriong } \\
\text { paßiong }\end{array}$ \\
\hline 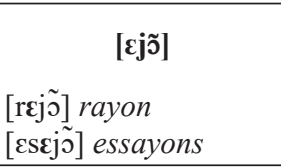 & аіон & $\begin{array}{l}\text { *Ayon какъ аіон, нъсколько въ } \\
\text { носъ } \\
\text { раіонъ } \\
\text { ессаіонъ }\end{array}$ & äjung & $\begin{array}{l}\text { *Ayon, fast wie äjung, } \\
\text { etwas durch die Nase } \\
\text { räjung } \\
\text { eßäjung }\end{array}$ \\
\hline 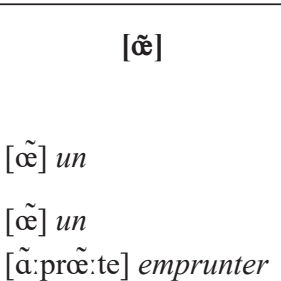 & $\begin{array}{c}\text { юнь } \\
\text { юн }\end{array}$ & $\begin{array}{l}N(\ldots) \text { Иначе *n съ } \\
\text { предстоящею предъ нимъ } \\
\text { гласною буквою въ носъ } \\
\text { ень } \\
\text { юнь } \\
\text { емпрюнте }\end{array}$ & & $\begin{array}{l}\text { Sonst wird das } * \boldsymbol{N} \text {, mit } \\
\text { seinem vorhergehenden } \\
\text { Vocal etwas durch die } \\
\text { Nase ausgesprochen } \\
\\
\text { üng } \\
\text { angprünteh }\end{array}$ \\
\hline
\end{tabular}

40 В издании 1780 г. с. 9 vien (sic). Можно восстановить vient или viens. Ошибка не исправлена в издании 1788 г.

${ }^{41}$ Первое лицо множественного числа имперфекта глагола passer. 


\section{2. Неточности и непоследовательность}

Как ни странно, понятие о «носовых гласных» появилось достаточно поздно во французской грамматической терминологии. В своем лингвистическом значении прилагательное nasal впервые появляется в словаре Французской академии только в издании 1762 г.: «nasal, ale, прил. Грамматический термин. О звуке, измененном произношением в нос в любом слоге, заканчивающемся на $m$ или $n$, предшествуемых гласной» ${ }^{42}$. Но еще в 1694 г. Данжо в своих «Эссе по грамматике», переизданных Оливе в 1754 г., уже говорил о «носовых гласных» [Rey 2008: 233-234]. И в самом деле все грамматики XVII-XVIII вв. придают особое значение носовым гласным. Они обычно рассматриваются как в описании произношения отдельных звуков, так и в разделах о долготе слогов, когда такие имеются в грамматиках. Тем не менее, когда дело доходит до подробностей, не всегда легко даже для современного носителя французского языка ориентироваться в некоторых указаниях. Как правило, учебники только объясняют, когда гласная должна произноситься «в нос» и когда, несмотря на присутствие $n$ или $m$, предыдущая гласная сохраняет оральный звук или вновь приобретает его вследствие деназализации.

Грамматика Пеплиера верна этой традиции. В статье $E m$, en перечисляются исключения, в которых вместо носового звука слышится [عm], [عn]: Jerusalem, examen, hymen. В той же статье описывается деназализация: «Em, en, естьли другая согласная буква сльдуетъ, произносится почти какъ ан нъсколько въ носъ (...). Выключается изъ сего правила 1) Буква $n$, Естьли другой $n$ за онымъ сльдуетъ; епnеті еннеми; кроме еппиі, которое слово произносится аннюи. (...) 4) естьли стоя́ть два $m$, то произносятся какъ ам, напр. Femme, emmener; говори фамъ, амене» [Пеплиер 1780: 6]. И дальше, в статье $M$ : «естьли согласная буква будетъ за нимъ сльдовать въ ономъ же словь, почти произносится какъ $n$ въ носъ (...) Выключаются «1) слова́, зачинающіяся съ $i m$, а притомъ естьли за онымъ $і m$ будетъ другое $m$ сльдовать, то объ буквы оныя ясно выговариваются immortel иммортель. 2) естьли за буквами $a$, o, также $e$ два $m m$ или $m n$ сльдуютъ; то выговаривается только одинъ $m$ или $n$, homme, омъ, condamner кондане ${ }^{43}$; femme фамъ» [Пеплиер 1780: 10].

Перевод грамматики Пеплиера правильно объясняет читателю, когда надо произносить гласную «в нос» и когда носовая согласная читается самостоятельно, но его описание конкретного звучания французских носовых оставляет желать лучшего. Выдуманы нигде не существующие тонкости: en выговаривается «почти» как an. Нет. Они звучат одинаково как [ã], или может быть

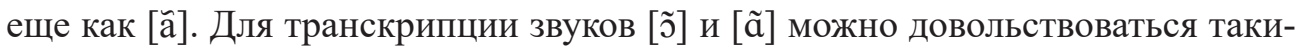
ми указаниями, как «ан» или «он», произносимые «нђсколько в носъ».

Но транскрипция таких звуков, как $[\tilde{\varepsilon}]$ или $[\tilde{\propto}] /[\tilde{\varnothing}]$, сбивает читателя с тол-

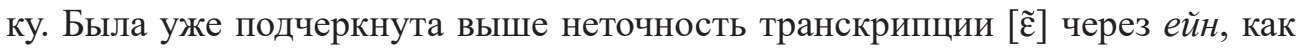
будто носовой слог содержит дифтонг и произносится с закрытым [е]. Но раз-

42 "Terme de grammaire, qui se dit d'Un son modifié par le nez, comme il l'est dans toute syllabe qui se termine par $m$ ou par $n$, précédés d'une voyelle" [Dictionnaire de l'Académie françoise 1762: II, 197].

43 В отличие от многих французских источников во «Французской грамматике» не упоминается при описании произношения слова condamner долгота второй гласной. 


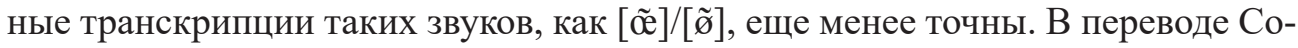

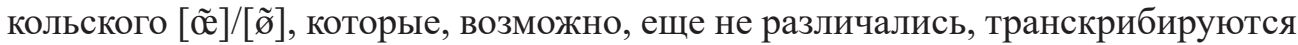
как бы наугад, то как ень (un ень [Пеплиер 1780: 17]), то как юн (emprunter емпрюнте [Пеплиер 1780: 6]), то как юнь (в другой транскрипции артикля иn [Пеплиер 1780: 13]). Что же могло оправдать ошибочную транскрипцию через ень? Известно, что современные носители французского часто грешат против орфоэпии, произнося $[\tilde{\propto}] /[\tilde{\varnothing}]$ как $[\tilde{\varepsilon}]$. Но для слияния $[\tilde{\propto}] /[\tilde{\varnothing}]$ и $[\tilde{\varepsilon}]$, которое, согласно литературной норме, еще не завершилось в XXI в., в XVIII в. безусловно еще рано. По всей видимости, здесь очередной раз отражается просто непоследовательность, с которой Сокольский соблюдает собственные правила в транскрипциях. Другие употребляемые транскрипции через юн или юнь так-

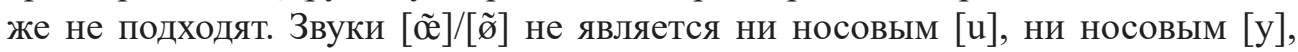

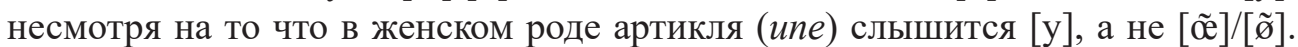

В логике системы транскрипции самого Сокольского единственным удовлетворительным и ожидаемым описанием $[\tilde{œ}] /[\tilde{\varnothing}]$ было бы «как

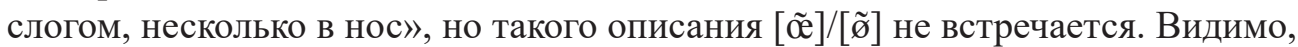
Сокольский плохо владел произношением французских носовых гласных, и в переводе он просто руководствовался ошибочным свидетельством оригинала, согласно которому иn читается как $\ddot{u n g}{ }^{44}$. Ошибка немецкой версии тем более удивительна, что если придать немецкому $g$ диакритическое значение для выражения носового признака, то очень легко условно передать французские $[\tilde{œ}] /[\tilde{\varnothing}]$ для немецкого читателя через ӧng.

Неточности транскрипции Сокольского не только дают плохое представление о реальных французских носовых гласных. Как было отмечено раньше, в ряде случаев они даже не позволяют отличать оральные $+[\mathrm{n}]$ от носовых гласных (une/un при юнь, -eine/-ein при ейнь и т. д.).

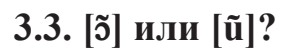

В защиту Сокольского подчеркнем, что французские источники почти никогда не дают прямых указаний о конкретном произношении каждой носовой гласной, как будто это и так само собой понятно французскому читателю. Бы-

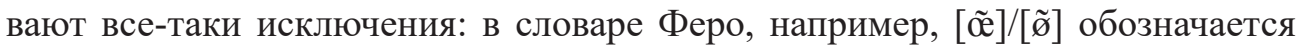
как eun, но в большинстве источников только скрещивая косвенные данные можно сделать вывод, что в какой-то период в XVII-XVIII вв. некоторые гласные произносили не так, как они произносятся сейчас. Достоверно установленные изменения касаются произношения om, on в любой позиции и in, im в начале слова.

В 1659 г. по свидетельству Шифле on, om не читаются как [ว̃], а еще как [ũ]: «Если после om и оп идет еще одна согласная, кроме $m$ и $n$, то om и on произносятся как oun, или как в латинском umbra, sunt, pungunt, например nombre, conference, ronce, respondre, ronfler, songer, congé, trompeur, quiconque, response, bonté, bronze и т. д.» ${ }^{45}$. В более поздних источниках уже не встречается

44 [Pepliers 1749: 10 и 12]: "finir un discours fini rüng discur".

45 "Si après $o m$ et $o n$, suit une autre consonne, que l' $m$ ou l' $n$, om et on se prononcent comme oun, ou comme en Latin, umbra, fum, pungunt" [Chiflet 1659: 17]. 
подобного замечания насчет on, om, а в словаре Феро лаконически говорится «On является носовой гласной» [Féraud 1768, II: 216], которая в словаре систематически транскрибируется как on. От произношения on, om как [ũ] не остается никакого следа. Стало быть, Сокольский прав: on - это просто он «нъсколько въ носъ».

\section{4. Сохранение одного архаизма - [ĩ] в начале слов}

При всей неточности в транскрипции носовых в переводе Сокольского обращает на себя внимание один момент - однозначное утверждение, что носовая, обозначаемая in, im в начале слов, отличается от носового звука, изображаемого теми же самыми буквами в других позициях, где in звучит точно так

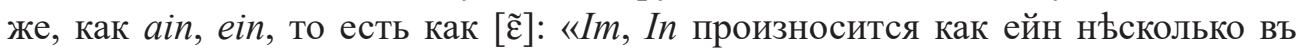
носъ, destin дестейнъ, timbre тейньбрь. Выключаются слова начинающіяся съ im, или in: imbu, имбю; index, индекс» [Пеплиер 1780: 9]. В немецком оригинале также значится: “Im, In, fast wie eing, etwas durch die Nase. (...) Nimm aus die Wörter, welche von im oder von in anfangen: Imbu, imbü; index, index" [Pepliers 1749: 7].

В современном французском языке in, ain, ein фонетически не различаются, и они все читаются одинаково как [г̃]. Изменилось ли произношение? Если верить Феро, бывший ректор парижского университета Шарль Роллен (16611741) «утверждает в своем Traité des études» ${ }^{46}$, что мы произносим Infini и подобные слова, как будто написано Ein-fini» ${ }^{47}$. И действительно, в течение XVIII в. ряд свидетелей подтверждает отсутствие разницы между in и ain, ein. Уже в первой четверти XVIII в. Жийе-Воделен транскрибирует одинаково на-

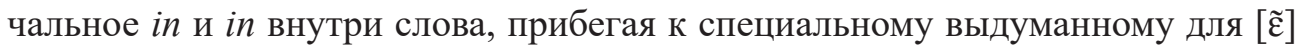
знаку (і с хвостиком). Но Жийе-Воделен передает только народное произношение ${ }^{48}$. Ла Туш пишет в 1730 г. «Произносите imbu, infini, vin, cousin, как aimbu, vain, cousain» ${ }^{49}$. Начальное in (как в прилагательном imbu, которое цитируется в грамматике Пеплиера) не отличается от in в других позициях (vin, cousin) и произносится как $[\tilde{\varepsilon}]$. В шестом издании «Начал» Вайи также утверждается, что «Im, in, ain, ein изображают тот же самый звук: impoli, cousin, la faim, la fin, le pain, la peinture» ${ }^{50}$. Заметим, что в этом списке тоже соседствуют слова с im, in начальными и in внутри слова. Наконец, в последней четверти века читаем у Домерга «In и ain, ein, aim и т. д. произносятся одинаково. Когда этот звук находится в начале слова, он пишется через in за исключением ainsi и ains, устаревшего слова, замененного ныне словом mais. Пишите injuste, intention» ${ }^{51}$.

46 Сокращенное название знаменитого труда в 4 томах “De la manière d'enseigner et d'étudier les Belles-Lettres par rapport à l'esprit et au cœur...”, Paris, 1726-1728.

47 "M. Rollin, dans son Traité des Etudes, assure que nous prononçons Infini, et autres mots semblables, comme s'il étoit écrit Ein-fini" [Féraud 1768, II: 14].

${ }^{48}$ См. i.a.rti. incertain [Gillet-Vaudelin 1713: 1].

49 "Prononcez imbu, infini, vin cousin, comme aimbu, vain, cousain" [La Touche, Regnier-Desmarais 1730: 8].

50 “Im, in, ain, ein ont le même son" [Wailly 1772: 196].

51 "In a pour identiques ain, ein, aim, etc. Ce son, lorsqu'il est initial, se rend par in, excepté dans ainsi, et dans ains, vieux mot que mais a remplacé. Écrivez injuste, intention" [Domergue 1778, 56]. 
Судя по этим источникам, произношение начального in не отличается от in в других позициях, и кажется, что здесь мы имеем дело с очередной ошибкой немецкого оригинала грамматики Пеплиера, не исправленной Сокольским при переводе.

Но на самом деле другие источники подтверждают, что во второй половине XVII в. начальное in еще отличалось от in в других позициях, имеющего звук ein, ain. В своих «Началах (...) о правильном произношении нашего языка» Лартиго употребляет свою оригинальную орфографию, выдуманную для точного воспроизведения произношения. Одной букве или одному сочетанию букв соответствует только один звук. Лартиго, в отличие от Жийе-Воделена, воспроизводит не народное, а литературное произношение, и в «Началах» читаем écrivein (écrivain через ein), но inconuёs (inconnues - через in) [Lartigaut

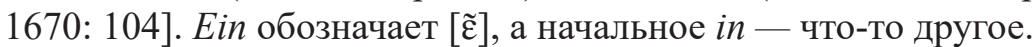

Внимательное чтение учебника Эндрэ подтверждает, что начальные $i m, i n$,

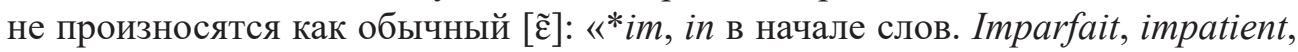
impie, impertinent, importun, imprudent, imputer, insolent, incommodité, incident, incision, injure, ingrat; in, когда [эти буквы] стоят после согласной или букв qu,

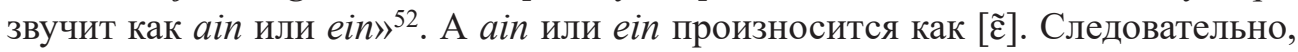
если верить Эндрэ, права грамматика Пеплиера: в начале слов $i m$, in не звучит как $[\tilde{\varepsilon}]$, а по-особому.

К середине XVIII в. Валлар еще разделяет мнение Эндрэ: «Сии три буквы (ain) выражают тот звук, который слышится в конце слов enfin, pin, vin. Этот звук слышится в конце слов plein, serein, sein и т. д., и он отличается от чистого звука гласной in, который слышится в первом слоге таких слов, как indigne, ingrat, inhumain [sic], insigne» ${ }^{53}$. Очевидно, что произношение в XVIII в. изменилось, и когда-то существовало особое произношение начального in, im, нашедшее свое отражение в грамматике Пеплиера.

Как показывает Феро, в середине XVIII в. оба произношения начального in сосуществовали. Впрочем, автор грамматического словаря принимает их оба, но он все-таки высказывается за особое произношение в начале слова: «In перед согласным есть простой звук, простая гласная носового типа, имеющая звук ein, когда in находится в середине или конце слов, и звук in в начале слов. Destin, incommode. Произносите des-tein, in-komode. (...) О. Бюффье утверждает, что лишь некоторые парижские буржуа и некоторые провинциальные образованные чудаки придают начальным in и im звук ein и произносят Einkapable, einpocible. Аббат Жирар разделяет мнение о. Бюффье» (о противоположном мнении Роллена см. выше $)^{54}$.

52 “*im, in au commencement des mots. Imparfait, impatient, impie, impertinent, importun, imprudent, imputer, insolent, incommodité, incident, incision, injure, ingrat. In précédé d'une consonne ou des lettres qu sonne comme ain ou ein" [Hindret 1687, 56].

53 "Ces trois lettres (ain) expriment le son que l'on entend à la fin de ces mots enfin, pin, vin, qui n'est point le son pur de la voiielle in tel qu'il est dans la première syllabe de ces mots indigne, ingrat, inhumain [sic], insigne; mais le son que l'on entend à la fin des mots suivans plein, serein, sein, etc." [Vallart 1744, 30].

54 "In devant les consonnes est un son simple, une seule voyelle du genre des nasales, qui a le son d'ein lorsqu'il est au milieu ou à la fin des mots, et le son d'in, quand il commence le mot Destin, incom- 
Итак, для начального in существовало еще особое носовое произношение наряду с новым [ع]. В конечном итоге странная на первый взгляд транскрипция начального $i n$, im через $u$, ин в грамматике Пеплиера не так уж ошибочна. В немецком оригинале она, наверно, отражает норму произношения того времени. Но в переводе она передает лишь один из двух возможных вариантов, самый старинный и уже вымирающий. В 1780 г. — это уже архаизм.

\section{4. Согласные звуки}

\section{1. Несколько слов о льезонах}

Произношение конечных согласных является одним из наиболее сложных вопросов французской орфоэпии, как сегодня, так и в XVII-XVIII вв. Что именно выговаривается и что опускается? Этой теме Пеплиер посвящает отдельный раздел конца первой главы - «О произношеніи согласныхъ словъ на концъ (sic) ${ }^{55}$ ». В общих чертах этот раздел построен по плану того же раздела в грамматики Шифле - Seconde partie, section septième. De la prononciation des consonnes finales devant les voyelles [Chiflet 1659: 204-215]. Подробный анализ трактовки проблемы в грамматике Пеплиера требовал бы отдельного анализа. Не входя в подробности, отметим только одно из достоинств грамматики Пеплиера: на протяжении всего нескольких страниц (14-19) «Французская грамматика» позволяет русскому читателю составить себе достаточно верное представление о сложном вопросе льезонов.

Для появления льезона в XVII-XVIII вв. должны быть выполнены четыре условия: 1) слово, заканчивающееся согласной, обычно немой, должно находиться перед словом, начинающимся с гласной или немого $h ; 2$ ) не должно быть паузы в потоке речи; 3) между обоими словами должна существовать тесная логическо-синтаксическая связь; 4) не должно быть инверсии обычного порядка слов: управляющее слово (le mot régissant у Эндрэ) должно предшествовать управляемому слову (le mot régi).

Такие авторы, как Шифле [Chiflet 1680: 242], подробно излагают последние два пункта. Льезон делается между предлогом и управляемым им словом, между прилагательным и существительным или между подлежащим и глаголом, но только если прилагательное предшествует своему существительному, подлежащее - своему глаголу. Если обычный порядок слов нарушен, чаще всего льезон уже невозможен. Кроме того, все авторы настаивают на необходимости учитывать слог: некоторые льезоны делаются даже в разговорном языке, иные только в публичной речи, в проповеди; другие необходимы лишь в чтении стихов.

Все эти элементы учитываются в грамматике Пеплиера: «По большой части согласныя на концъ словъ не выговариваются. Выключаются 1) с, s, 1, r, 2) естьли сльдующее слово съ гласной буквы начинается. (...) Многія со-

mode. Prononcez des-tein, in-komode. (...) Le P. Buffier prétend qu'il n'y a que quelques Bourgeois de Paris et quelques beaux esprits de Province, qui donnent à in et à im, commençans le mot, le son d'ein, et qui prononcent Einkapable, Einpocible. L'abbé Girard pense comme le P. Buffier (...) L'usage et les opinions sont donc partagés pour le commencement des mots, et nous n'oserions rien décider là-dessus." [Féraud 1768, II, 14].

55 Von den Consonanten am Ende der Wörter [Pepliers 1749: 11]. 
гласныя въ разговорахъ умалкиваемы бываютъ, а въ ръчахъ большихъ и стихахъ произносятся. Слова̀, имђющія союзъ свойства̀, которыя безъ нарушенія смысла раздълиться не могутъ, всегда въ произношеніии одно съ другимъ связываются» [Пеплиер 1780: 14-15].

В общих чертах принципы реализации льезонов и произношения конечных согласных изложены верно.

\section{2. Произношение губных, зубных, задненебных, носовых и дро- жащего согласных звуков}

В отличие от гласных, французские согласные звуки [b], [p], [v], [f], [m], $[\mathrm{d}],[\mathrm{t}],[\mathrm{z}],[\mathrm{s}],[\mathrm{g}],[\mathrm{k}],[\mathrm{r}],[\mathrm{n}]$ не вызывают особых трудностей для носителя русского языка. Каждый из них обозначается Сокольским при помощи одной буквы русского алфавита без дополнительных объяснений.

И объяснений в самом деле почти не нужно. За следующими исключениями:

1. Насчет транскрипции французского [g] через г было бы уместно уточнить, что речь идет о взрывном [г], а не о фрикативном [ү] малороссийского происхождения, употребляемом в XVIII в. в высоком стиле в качестве церковнославянизма ${ }^{56}$.

2. Для точности описания следовало все-таки уточнить, что перед гласными переднего ряда [i], [у] французские согласные не смягчаются. Это особенно важно для правильного произношения французских взрывных альвеолярных [d] и [t] и различения сочетаний звуков [n] с гласной и [n] с гласной.

a) Действительно, поскольку в русском языке возможны только либо сочетания твердый $\left[\right.$ д $\left.^{\circ}\right]$ или $\left[\mathrm{T}^{\circ}\right]+[\mathrm{I}]$, либо мягкий [д’] или [т’] + [и], при произношении французских сочетаний [di], [ti] русскоязычные автоматически смягчают зубную согласную, что и вызывает появление свистящего призвука, который является типичным признаком русского акцента даже у многих носителей русского, которые давно и отлично владеют французским.

б) Что же касается [n], еще очевиднее необходимость уточнить, что во французском он всегда произносится твердым. Без такого уточнения остается непонятным, например, комментарий Сокольского к произношению глаголов signer, signifier. В современном французском языке gn в этих словах читается по общему правилу — как [n]: [sine], [sinifje]. Но в XVII-XVIII вв. слово signer и производные составляли исключение, и, несмотря на орфографию, которая с XVII в. не изменилась, буквы gn читались как простое $n$, то есть [n]: [sine], [sinifie]. Для обозначения последних реализаций в переводе грамматики Пеплиера приводятся транскрипции сине, синифіе. Руководствуясь этим указанием, русский читатель прочтет слоги не, ни через русский мягкий [н'], то есть практически как французский [n], как раз чего и хотелось избежать. Дело в том, что для передачи [n] Сокольский прибегает к сочетанию нb. Слово gagner он транскрибирует как ганье, что и вызывает новую неточность: русскому читателю покажется, что нье обозначает присутствие [j] после носовой.

56 См. знаменитое стихотворение Ломоносова «О сомнительном произношении буквы Г в Российском языке», цитируемое М. В. Пановым [2002: 367-368]. 
Но на самом деле французский [n] отличается от [nj]. Есть ли выход? Для правильного обозначения твердости носовой в глаголе signer существовал простой вариант - синэ. Но тогда возникла бы новая неточность, так как автор русских транскрипций решил придать графеме э условное значение открытого [ع], а графеме $e$ значение закрытого [е] (см. выше в разделе о гласных prêter [prete] nрэте). А окончание инфинитива signer содержит не открытое $[\varepsilon]$, а закрытое [е]. Поэтому сама система, выбранная переводчиком, воспрещала ему пользоваться здесь буквой э: в своих транскрипциях Сокольский пожертвовал обозначением твердости или мягкости предыдущей гласной обозначению качества гласной. Иными словами, в оппозиции согл.+э/согл.+e выбранная графема указывает на открытость или закрытость гласной, но выбор е отнюдь не значит, что предыдущая согласная смягчается.

Автору перевода следовало только уточнить, что французские [n] всегда произносятся без смягчения независимо от следующей графемы русской транскрипции, и противоречивость указаний о signer, signifier были бы устранены. Сине русский читатель мог бы прочитать правильно - [sine].

3) Реализация фонемы /r/, которая в XX-XXI вв. стоит столько усилий русскоязычным, не вызывала тогда никакой трудности: французская /r/ XVIIXVIII вв. произносится как русский дрожащий [r]. Современное увулярное произношение этой гласной [в], которое уже иногда встречалось в народе в Париже, считалось либо вульгарным, либо дефектным. Как известно, в знаменитой 4-й сцене 2-го действия «Мещанина во дворянстве» Мольер описывает артикуляцию [r] своего времени, то есть именно дрожащего, русского [r]. И всегда смешно зрителю, имеющему хоть некоторое представление об артикуляционной фонетике, когда современные актеры во всех подробностях описывают г. Журдену все тонкости дрожащего [r], а при том на сцене упорно произносят увулярный $[\text { в }]^{57}$. Напомним, что до смут революции орфоэпической нормой еще являлось придворное версальское произношение. Особенности парижского просторечия, долженствующие впоследствии вытеснить нормативные [wع] или дрожащий [r] в пользу современных реализаций [wa] и [в], приравнивались большинством авторов к диалектизмам наряду с другими ошибками в произношении провинциалов.

\section{3. Шипящие}

Французские [J] и [3] вызывают трудности для немецкой транскрипции. Фонема [S] существует в немецком, но ее звонкий вариант - нет. В немецкой версии грамматики Пеплиера [3] описывается как «еtwas leiser als sch» [Pepliers

57 “MAÎTRE DE PHILOSOPHIE. — Et l'R, [se prononce] en portant le bout de la langue jusqu'au haut du palais ; de sorte qu'étant frôlée par l'air qui sort avec force, elle lui cède, et revient toujours au même endroit, faisant une manière de tremblement, RRA. / MONSIEUR JOURDAIN. - R, R, RA; R, $R, R, R, R, R A$. Cela est vrai. Ah l'habile homme que vous êtes ! et que j'ai perdu de temps ! R, r, r, ra." («Учитель философии. Р произносится посредством поднятия кончика языка к небу; от напора воздуха, который мы выдыхаем, он колышется и как бы дрожит: Рp, РА... / Журден. Рp, Pp, PA; Pp, Pp, Pp, Рp, Рp, РА... Верно! Чудодей вы этакий! Эх, сколько я времени потерял!.. Рp, Рp, Рp, PА...». Мольер. Мещанин во дворянстве. Действие II, явление 4-е). Полное собрание сочинений в одном томе. М.: Издательство АЛЬФА-КНИГА, 2009. Перевод В. Лихачева). 
1749: 6]. Зато в русском языке, как во французском, существуют парные простые шипящие - звонкая /ж\% и глухая /ш\%. Французский звонкий звук [3] транскрибируется через ж, а его глухой эквивалент - через $m:$ « $G$ предъ буквами $e, i$ и $y$, выговаривается какъ ж; Ch выговаривается какъ $u »$ [Пеплиер 1780: 4 и 7]. Тем не менее, этих указаний недостаточно, чтобы дать русскому читателю точное понятие о произношении французских шипящих. Русский $\left[ш^{\circ}\right]$ значительно тверже французского [S], который в свою очередь не так мягко произносится, как русский [щ']. Было бы желательно уточнить, что французские шипящие произносятся твердо, но не так твердо, как в русском. Стоило бы также подчеркнуть, что после [3] и [S] французская фонема /i/ произносится как [i] несмотря на отсутствие смягчения, и после шипящих французская /i/ никак не переходит в [i].

\section{4. Лабиопалатальный аппроксимант [ч]}

Помимо $[w]$ и [j], известных в большом количестве языков, существует во французском языке еще один, менее распространенный полугласный звук лабиопалатальный аппроксимант [ч]. Этот полугласный звук соответствует гласному [у]. Оба звука, [у] и [ч], чужды русскому языку. Как правило, французские грамматики XVII-XVIII вв. не посвящают полугласной [ч] отдельных замечаний. Дело в том, что в некоторых позициях - в первую очередь после задненебных и перед гласной переднего ряда $-[y]$ автоматически переходит в [ч], если сочетание согласная+[у]+гласная переднего ряда произносится одним слогом, см. cuisiner [kyi-zi-ne] ${ }^{58}$. В той же позиции перед гласной заднего ряда $[\mathrm{u}]$ переходит в $[\mathrm{w}]$ : aquatique [a-kwa-ti-kə] ${ }^{59}$ Звук [ч] не воспринимается эксплицитно грамматиками XVII-XVIII вв. как отдельный звук, а всего лишь как разновидность обычного $[\mathrm{y}]^{60}$.

Тем не менее, наличие [ч] можно вывести из деления слова на слоги, особенно в словаре Феро, или же - в том же труде — из таких замечаний, как «Nui всегда является дифтонгом и произносится одним слогом» ${ }^{61}$. В грамматиках и орфоэпических трактатах о звуке [ч] имплицитно пишут преимущественно в обсуждении списков исключений, в которых буква $u$, предшествуемая $q$ или $g$, не является немой, т. е. когда она не просто входит в диграф $q u$ или служит указанием на произношение $g$ как $[\mathrm{g}]$ перед $e, i, o$. Комментируя эти исключения, авторы как правило уточняют, что $u$ произносится. А франкоговорящий читатель в этой позиции несознательно произнесет этот [у] не как гласный, а как полугласный [ч].

58 "kui-ziné, trois brèves" [Féraud 1768, I: 309].

59 "L'u y a le son d'ou. A-koua-tique" [Féraud 1768, I: 78].

${ }^{60}$ Когда в грамматиках объясняют, как отличать $u(v)$ voyelle от $u(v)$ consonne или $i(j)$ voyelle от $i(j)$ consonne, речь идет не о разнице между [y] и [ч], [u] и [w], а только о графемах: о тех случаях, когда $u$ употребляется со значением современного $u$ и со значением современной графемы $v$; когда $i$ употребляется как современная буква $i$ и как современная буква $j$. Еще в издании 1768 г. словаря Феро $u$ и $v, i$ и $j$ в алфавитной классификации слов считаются одной буквой, хотя они уже давно употребляются по-современному, в том числе и в самом словаре.

${ }_{61}$ "Nui est toujours diphtongue et d'une seule syllabe" [Féraud 1768, II: 196] 
Различие между [y] и [ч] такая тонкость языка, что сами авторы орфоэпических учебников - носители французского языка не обращают на него внимания и реализуют полугласный звук несознательно, думая, что они выговаривают обычный гласный звук [у]. Поэтому замечательно, что в транскрипциях грамматики Пеплиера, как в немецком оригинале, так и в русском переводе, [ч] всегда отличается от [у]. Последнее передается буквой ю, а для обозначения [ч] употребляется [в], что и доказывает, что авторы правильно воспринимают этот звук скорее как согласный. Примеры достаточно многочисленны: cuir [kцir] (нем. kwire); aiguiser [вgчize] егвизе (egwisch, sic) ${ }^{62}$; [G] uise [gчi:zə] гвизе gwise ${ }^{63}$. После [z] — dix-huit [di(:)zчit] дизвить (dihswit). Судя по указаниям Феро, можно исключить приводимое Пеплиером cuiller [kyКe [Féraud 1768]/kyКcr] квилльерь (kwüljere) и также aiguille егвиль (egwille). В современном французском произношении, после перехода $[\Lambda]$ в [j], aiguille в самом деле содержит [ч], но в XVII-XVIII вв. $i$ имеет здесь лишь диакритическое значение для обозначения наличия $[K]$, и слово произносится [عgуКә]. Здесь в самом деле слышится гласная [y], а не полугласная [Ч], и транскрипция Сокольского ошибочна. Но в остальных случаях она соответствует норме его эпохи.

Транскрипция [ч] посредством в или $w$ превосходит французские транскрипции, выделяя полугласный статус [ч]. Но при том ни немецкая, ни русская транскрипция не способны отличать [ч] после задненебных от другого полугласного - $[\mathrm{w}]$. Это особенно заметно в транскрипции слов, содержащих диграф qu. По общему правилу qu читается как [k], буква $u$ немая. Когда же $u$ не является немым, бывают два типа исключений: либо qu читается как [kw] (équateur, quadrature, aquatique), либо - в единичных случаях — qu обозначает [ku] (équestre) ${ }^{64}$. Однако немецкие и русские издания грамматики Пеплиера не различают этих случаев и транскрибируют их одинаково: equestre еквестерь (sic) (ekwäster) ${ }^{65}$; equiangle еквианль (ekwiangle); quinquagésime квинкважесимъ (kwinkwascheschime); aquatique акватикъ (akwatike); quadragénaire квадражесимъ (sic) ${ }^{66}$ (kwadraschenähre); quadrature квадратюръ (kwadratüre); еquateur екватіоръ (ekwatör).

\section{L et L mouillée (твердый [1] и мягкий [К])}

Одним из главных изменений в орфоэпической норме французского языка с конца XIX в. является переход произношения так называемой $l$ mouillée (мягкой $l$ ) в йот, вытеснивший боковой палатальный сонант [K], который считался нормой в XVII-XVIII вв. и вплоть до XIX в. Переход от $[K]$ к [j] можно

62 В отличие от остальных источников Феро указывает на произношении [gi] без [Ч].

63 В грамматике Пеплиера слово пишется без прописной буквы. Но согласно источникам XVII-XVIII вв. [Ч] появляется только в знаменитой фамилии, а guise существительное произносится [gi:zə] без [Ч].

64 "é-kuès-tre, en trois syllabes" [Féraud 1768, I: 140]. См. также «Произносите $q$ как $c$ в équestre, или еще лучше - добавьте одно $и$ и пишите équuestre» ("Prononcez le $q$ en $c$ dans équestre ou plûtôt ajoutez-y un $u$ et écrivez équuestre") [Vallart 1744: 18].

$65 \mathrm{Sic}$ с метатезой $е$ и $r$.

66 Оплошность издания 1780 г. не исправлена в издании 1788 г. 
считать делатерализацией исходного звука. По всей видимости, изменение это в ненормативном произношении началось довольно рано, задолго до перевода грамматики Пеплиера. Еще в конце XVII в. Эндрэ замечает, что «среди парижской мелкой буржуазии встречаются многие люди, которые (...) вместо bataillon, postillon, bouteillé (sic), moüillé, boüillon и других слов, в которых встречается $i$ с двумя мягкими $l l$, говорят batayon, postiyon, boutaye, boüyon» ${ }^{67}$. Безусловно, Эндрэ — консерватор. Нормативному ill $[K]$ он противопоставляет народный $y[\mathrm{j}]$.

Несколько лет спустя Жийе-Воделен снисходительнее отнесется к этому дефекту парижской простонародной речи: «Когда парижские ремесленники говорят ипе [fijə] (fille), de la [ргjə] (рауе)... они отлично произносят дифтонг [jə]. Из этих слов они опускают только согласную L, которая — как все остальные согласные - естественно становится несколько неясной перед такой краткой и неясной гласной, как [јə], или рядом с ней» ${ }^{68}$. Тем не менее, автор самой близкой к народному произношению системы фонетической транскрипции языка первых лет XVIII в. не опускает «L» в своей транскрипции $l$ mouillée, которая передается им как lie, формально - [ljə]. Получается, что для ЖийеВоделена все-таки важнее сохранить элемент «L», допуская легкую неточность (мягкий [K] отличается как от простого [j], так и от [1]+[j]), чем принять простонародное произношение без [1]. Видимо, даже для такого «народного» автора произношение $l$ mouillée как простой [j] еще режет слух.

И в самом деле, в конце интересующего нас периода нормативный словарь Феро резко осуждает сведение $l$ movillée к [j]: «У итальянцев существует похожий звук - их gli, и слово [французское] bataille произносится, как будто написано bataglie. Испанцы же имеют $l l$, которые произносятся мягко: llamar, и т. д. Очень часто искажают произношение мягкой $l$. Произносят fie, oréye, versaye, и т. д., что и является грубой ошибкой, которая встречается не менее часто в Париже, чем в провинциях» ${ }^{69}$. Еще в 1778 г. Домерг при всей своей прогрессивности резко осуждает произношение Versailles через [j] вместо [ $К$ ] [Domergue 1778: 46].

Итак, пытаясь передать произношение l mouillée как [К], а не как [j], грамматика Пеплиера верна орфоэпической норме своего времени. В немецкой версии обозначение не существующего в немецком $[\Lambda]$ проблематично. Услов-

67 "Si nous examinons la petite bourgeoisie de Paris, nous trouverons beaucoup de gens qui (...) pour dire bataillon, postillon, bouteillé (sic), moüillé, boüillon et autres mots où ils entendent des $i$ accompagnez de deux $l l$ moüillées disent batayon, postiyon, boutaye, boüyon" [Hindret 1687: 9-10].

68 "Quand les Artisans de Paris disent, une [fijə] (fille), de la [pcjə] (paye)... ils prononcent parfaitement la Diphtongue [jo]; et ils ne retranchent de ces mots que la seule Consone L, qui (comme toutes les autres Consones) devient naturellement un peu obscure devant et avec une Voyelle breve et obscure telle qu'est [jə]" [Gillet-Vaudelin 1713: 14]. Мы передали современным международным фонетическим алфавитом специальный характер, выдуманный Жийе-Воделеном для обозначения звуков [jə] ie. Поскольку этот оригинальный знак состоит из округленной лигатуры гласных і и е, автор называет обозначаемый им звук «гласной» [jə].

69 'Les Italiens ont un son semblable, c'est leur gli, et bataille se prononce comme s'il s'êcrivoit batâille. C'est une prononciation très-vicieuse que celle qu'on substitue très-communément à celle de l'l mouillée. On prononce fie, oréye, versaye, etc. Ce défaut n'est pas moins commun à Paris que dans les Provinces." [Féraud 1768, II: 73]. 
но употребляется в качестве диакритического знака буква $g^{70}$ : «Ill, fast wie ilg. Fille, filge; $I l$, fast wie $i l g$, so, daß sie beyde zusammen in einander schmelzen. Mil, milg; ail, ölg [Pepliers 1749: 7]; *Eil fast wie elg, mit etwas anstossender Zungen. Soleil, ßolelg [Pepliers 1749: 5]; * Ail fast wie alg, mit etwas anstossender Zungen, das $l$ und $g$ wie in einander schmelzen. Travail, $\operatorname{travalg}^{71}$ [Pepliers 1749: 3]. Напомним, что в оригинале и переводе знаком * перед транскрипцией обозначаются звуки, «изученію которыхъ учиться должно изустно» [Пеплиер 1780: 7]. Этот знак отсутствует в немецкой версии только перед Ill, по всей видимости это оплошность.

В русском переводе знак * присутствует только перед * Ail и * Eil, хотя в русском языке существует звук, весьма близкий к французскому [K]: «Ill произносится такъ почти какъ iль; fille, филь; Il выговаривается почти какъ иль, такъ чтобы сіи объ литеры въ одну сливались mil, миль ; œil eль», пишет переводчик Пеплиера [Пеплиер 1780: 9]. «*Ail выговаривается какъ aль: travail, траваль, но выговоръ быль бы мокрымъ языкомъ, и языкъ какъ будто бы обо что ударялся» [Пеплиер 1780: 3]. «*Eil такъ почти выговаривается, как Руское eль, только чтобы языкъ какъ буттобы обо что ударялся: Soleil, солеиль». Заметим, что в этом примере указания о произношения eil и транскрипция примера противоречат друг другу: вместо ожидаемого «ель» транскрипция слова Soleil содержит ненужное «и» (солеиль). При том опечатка издания 1780 г. (c. 6) сохраняется в издании 1788 г. (с. 5). Но ecueil транскрибируется ниже без «и»: екель [Пеплиер 1780: 14]. Кроме того, для транскрипции ill предлагается іль - через і десятеричное, а пример транскрибируется через $и$ осьмеричное. Но из анализа главы о произношении обоих изданий перевода Сокольского очевидно, что разница между $и$ и $i$ нерелевантна.

В общих чертах описание Пеплиером звука $[K]$ и обозначение его посредством ль правильны. Если $[K]$ произносится «такъ почти какъ ль», в чем состоит разница? Скорее всего, речь идет о небольшой разнице в точке артикуляции: русский мягкий [л'] произносится кончиком языка ближе к зубам, а судя по сохранившимся вариантам $l$ moӥillée в современных романских языках, как испанский и итальянский, французский $[K]$ произносился ближе к нёбу.

В итоге Сокольскому не было трудно найти способ дать русскому читателю верное представление о французском l mouillée. Его главная задача состояла не в описании звука, не очень чуждого для русского слуха, а в указании тех случаев, когда сохраняется обычный [1] («слова, начинающіяся съ ill, illegitime иллежитимъ, illustre иллюстр, сльдующія слова: Argille, Achille, imbécille, mille, pupille, syllabe, tranquille, ville» [Пеплиер 1780: 9]), в то время как по приведенным общим правилам можно было ожидать [К].

В разделе о произношении конечных согласных [Пеплиер 1780: 16] обсуждается особое произношение местоимения $i l$ и приводится список слов на $-i l$, в коих $l$ не произносится и конечным звуком которых является [i]: chenil, baril,

70 В немецкой версии грамматики Пеплиера $g$ также употребляется для условного обозначения носовых.

71 Sic, через $v$ вместо $w$. 
nombril, persil, sourcil, outil, но не упоминается слово avril, в котором конечный $-i l$ произносится [K] несмотря на то, что -il идет за согласной буквой ${ }^{72}$.

Но мог ли Сокольский однозначно обозначить правильную артикуляцию -il в конце слова avril? Если в немецкой версии грамматики сложно передать $[\Lambda]$, то с обозначением обычного [1] в немецком нет проблемы - немецкое $l$ произносится как французский [1]. А при переводе на русский - все наоборот. [К] достаточно легко обозначить, но как передать конечный [1], при том обозначая его так, чтобы русский читатель не мог перепутать его со своим

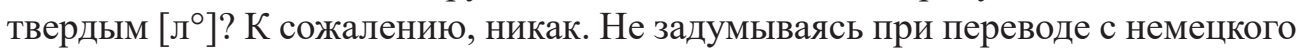
или исходя из того, что [1] является произношением по умолчанию французской буквы $l$, Сокольский передает звук [1] посредством простой русской буквы $л$ без дополнительных объяснений. «L произносится какъ Россійское $л »$ [Пеплиер 1780: 10]. Приводится список из нескольких слов, в которых $l$ пишется, но совсем не произносится в обычной речи, как quelque и quelqu'un (вопреки современной норме), но не приводится здесь примеров с обычным [1]. Их надо искать в других разделах: Laon Ланъ, fol amour фоламуръ, philosophe философъ, javelot жавелотъ, valet вале, gobelet гобеле, Hierusalem жерузалемъ (sic), parlez парле, joli жоли. Сразу заметно, что внутри слова обозначение звука [1] через л не может не ввести русского читателя в заблуждение: без дополнительных указаний перед гласной переднего ряда (керель, вале, гобеле, Жерузалем, парле, жоли) он будет произносить мягкий [л’], напоминающий французскому слуху скорее [K], чем [1]. А перед гласными заднего ряда (Ланъ, фоламуръ, философъ, жавелотъ) русский читатель будет произносить твердый $\left[\pi^{\circ}\right]$, совершенно чуждый французской фонетической системе. Ясно, что из двух ошибок произношение французского [1] как [л'] все-таки лучше, чем

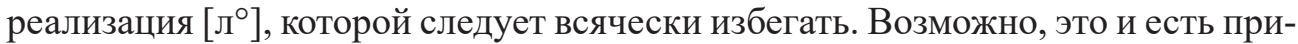
чина, по которой помимо других неточностей и ошибок ${ }^{73}$ в транскрипциях [1]

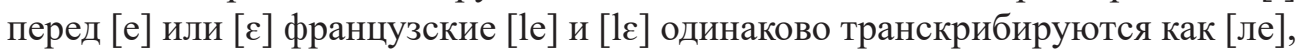
вопреки установленному Сокольским правилу, по которому закрытое [е] обозначается буквой $e$, а открытое $[\varepsilon]$ - буквой э. В транскрипции parlez ожидалось парле, но в транскрипции valet, gobelet, Hierusalem с [ع] ожидалось не $e$, а э (валэ, гоб(е)лэ, Жерюзалэм). По всей видимости, разница между [е] и [ع] была нейтрализована Сокольским после [1] именно во избежание произноше-

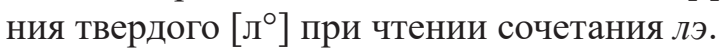

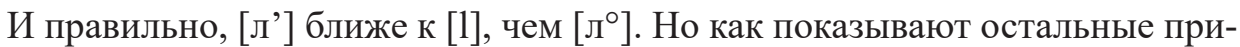
меры, если [1] транскрибируется как [л’], то в конце слов полностью утрачивается в транскрипции разница между [K] и [1]: vole воль, viol віоль, immortel иммортель, miel мьіель, il parle и парль имеют [1] или [1ə] в конце; seul сі̂оль заканчивается на [1], а они все транскрибируются как слово travail траваль, имеющее конечный $[\Lambda]$.

72 «A-vril. Со смягчением конечной $l »$. (Prononcez A-vril. Mouillez l’l finale) [Féraud 1768, I: 119].

${ }^{73}$ Hierusalem c [y] («ю»), а не [u] («у»); $t$ в конце javelot немой, и т. д. 
Неважно, что Пеплиер забыл упомянуть конечный [К] слова avril: с системой транскрипции Сокольского русский читатель все равно не мог бы понять, каким звуком заканчивается «авриль»: на мягким [К] или обычным [1].

\section{5. Выводы}

Итак, какое представление о французской фонетике своего времени мог себе составить русский читатель по прочтении первой главы перевода Сокольским «Французской грамматики» Пеплиера? Представление весьма упрощенное, запутанное и в итоге не очень адекватное.

С трудностями передачи звуков, не существующих в одном языке, буквами другого языка Ф. Сокольский справляется так себе, но не хуже, чем в немецком оригинале, когда $[\kappa]$ передается при помощи $l g$, например. Недостаток перевода Сокольского заключается не в неизбежной неточности, а в неоднозначности некоторых условных транскрипций и в непоследовательности в применении предлагаемой системы.

В момент появления русского перевода «Французской грамматики» Пеплиера оппозиция гласных по долготе еще живуча и оперативна на фонематическом уровне во французском языке. Русская версия ничуть не отражает системности этой оппозиции, и этот пробел является самой большой слабостью фонетической части грамматики Пеплиера и ее перевода. Как мы видели, Сокольский довольствуется переводом пар замечаний, уже присутствующих в немецкой версии, - об орфографическом значении «облеченного ударения» и о роли «безгласного е» как указателя долготы предыдущей гласной.

Но по вопросу оппозиции по долготе перевод Сокольского даже значительно отстает от оригинала. При немецкой транскрипции [е] через $\mathrm{eh}$, буква $h$ после $е$ употребляется для обозначения закрытости гласной, и здесь нейтрализуется в транскрипции оппозиция между [е] (parlerai, parlereh) и [е:] (parlez, parleh [Pepliers 1749: 4]). Но в ряде случаев в транскрипции примеров с долгим вариантом гласной в немецкой версии вслед за гласной графемой, используемой для изображения самого тембра гласной, употребляется еще и буква $h$ в ее обычной в немецком языке функции указателя долготы предыдущей гласной: [u:] (boue, buh, но bu в транскрипции слова bout с кратким [u] [Pepliers 1749: 8]); [o:] (beau, boh [Pepliers 1749: 5]); долгое еи в beurre (böhre), heure (öhre) [Pepliers 1749: 5], [i:] vie (wih) и т. д. [Pepliers 1749: 4]. Правда, долгота гласной в немецком оригинале указывается непоследовательно (долгота [є:] указана в prähteh prêter, но не в bät bête [Pepliers 1749: 4]) и допускаются редкие ошибки (kuhr cour, хотя здесь [u] краткий [Pepliers 1749: 8]). Зато в переводе Сокольского эти указания долготы совсем не отражаются, и все эти долгие гласные он транскрибирует как их краткий вариант (бу, бо, біоеерь, iôеръ, ви). Конечно, в русской орфографии не существует уже готового общепринятого указателя долготы, но и Сокольскому ничто не мешало выбрать любой условный знак.

Изменения тембра, сопровождающие удлинение гласных $([\mathrm{a}:] \neq[\mathrm{a}],[\mathrm{o}:] \neq$ [э]), были уже отмечены в момент издания Французской грамматики. Но о них нет речи ни в оригинале, ни в переводе Сокольского. 
В конце XVIII в. французская орфоэпия еще требует дрожащей реализации фонемы /r/. В Париже в простом народе уже можно услышать [R] или современный $\left[\right.$ в], но образованные люди произносят $[\mathrm{r}]^{74}$. Здесь Сокольский в своей лаконичности прав — «R произносится какъ Россійское $p$ » [Пеплиер 1780: 12].

Звук французского l moӥillée [К] во второй половине XVIII в. сохраняется. Его реализация уже изменяется в народе, но переход в [j] еще не известен литературному языку. Сокольский описывает звук довольно удовлетворительно, как нечто близкое к русскому [л’], и не путает его с [j]. Но двусмысленность транскрипции ль и непоследовательность, с которой Сокольский соблюдает собственные правила, ведут к тому, что в его переводе не различаются французские конечные [1] и [К].

В переводе Сокольского транскрипция носовых весьма туманна и непоследовательна. Достаточно верно описаны случаи деназализации, но для произношения носовых звуков русский читатель может опираться только на описания носовых гласных (по схеме «данная гласная произносится несколько в нос»), но не на транскрипции. В некоторых случаях странный выбор переводчика приводит даже к одинаковой транскрипции носовой гласной и ее ораль-

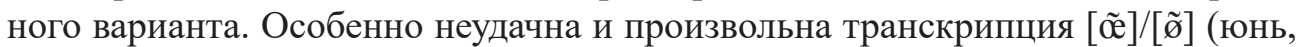
юн, ень). По всей видимости, Сокольский не владеет произношением французских носовых. На фоне такой путаницы удивительно, что «Французская грамматика» однозначно выступает за сохранение начального [1̃]. «Французская грамматика» защищает здесь очень консервативную позицию. Вероятно, если бы Сокольский имел более тонкое знание произношения французских носовых своего времени, он бы устранил при переводе архаизм, которым являлось в 1780 г. сохранение начального [ĩ], нормативного в момент сочинения немецкого оригинала.

Но, как и В. Теплов, Ф. Сокольский при переводе остается очень верен оригиналу. Даже в фонетике, той части грамматики, которая по своей природе требует от переводчика наибольшей адаптации для русской публики, Сокольский проявляет минимальную самостоятельность, за одним особенно замечательным исключением - вопреки немецкому источнику переводчик выбирает новый [wa] вместо традиционного [wع], даже без указания на существование [we] как равноправного варианта. Единственная заметная инициатива переводчика поражает своей прогрессивностью. Чем же объясняется противоречивость выборов Сокольского - сохранение архаизма и введение новейшей черты живого языка? Вряд ли Сокольский осознавал архаичность [ĩ]. Зато на русский слух разница между [wa] и [wع] очевидна. Если Сокольский имел случай общаться с носителями французского языка младшего поколения, неадекватность описания oi как ӧ̈ не могла не поразить его. Как бы то ни было, непоследовательность его выбора придает фонетической части «Французской грамматики» довольно пестрый характер. И поэтому совершенно неоспоримо лишь заключение ее первой главы: «произношенію учиться должно изустно».

74 Вибрации были более или менее сильны в зависимости от позиции фонемы в слове, см. [Féraud 1768, II: 385]. 


\section{ИСТОЧнИКИ}

\section{Грамматика Пеплиера}

Пепліеръ. Французская грамматика, при которой Исправньйшій Словарь, Дружескіе разговоры, Пословицы, Достойныя примъчанія Исторіи и пристойныя на разные случаи пи́сма. Изданная на нъмецкомъ языкъ Г. Пепліеромъ. А на Россійской переведенная п.с.к. Федоромъ Сокольскимъ.

- Москва: В Университетской типографіи у Н. Новикова, 1780.

- Москва: В типографіи компаніи типографической, 1788.

Pepliers Jean-Robert des. Nouvelle et parfaite Grammaire royale françoise et allemande. Neue und vollständige königliche französische Grammatik (...) des Herrn des Pepliers, vielmals herausgegeben, gegenwärtig aber durchgehends aus des berühmten französischen Jesuiten, Hrn. Buffier, und anderer Gelehrten Anmerckungen auf das fleißigste verbessert.

- Berlin: Völker, 1689.

- Berlin: Johann Chr. Pape, 1719.

- Leipzig: in der Weidmannischen Buchhandlung, 1749.

- Leipzig: in der Weidmannischen Buchhandlung, 1756.

\section{Использованные источники о французском произношении XVII-XVIII вв.}

Buffier Claude. Grammaire françoise sur un plan nouveau pour en rendre les principes plus clairs et la pratique plus aisée. Paris: Chez Nicolas Le Clerc, Michel Brunet, Leconte et Montalant, 1709.

Chiflet Laurent. Essay d'une parfaite grammaire de la langue françoise.

- Anvers: Jacques van Meurs, 1659.

- Cologne: chez Pierre le Grand, 1680.

Dictionnaire de l'Académie françoise, 1762 (quatrième édition). T. I. A-K. VII-683 p. ; T. II. L-Z. 661 p.

Domergue Urbain. Grammaire françoise simplifiée ou traité d'orthographe avec des notes. Lyon: Chez l'Auteur. 1778.

Féraud Jean-François. Dictionnaire grammatical de la langue françoise. Nouvelle édition revue, corrigée, et considérablement augmentée. Tomes I et II. Paris: Chez Vincent, 1768.

Hindret Jean. L'Art de bien prononcer et de bien parler la langue françoise dédié à Monseigneur le Duc de Bourgogne. Paris: Chez Laurent d'Houry, 1687.

Lartigaut Antoine. Les Principes infaillibles et les regles assurées de la juste prononciation de nôtre langue. Ouvrage d'une recherche toute particuliere, nécêsere à tous les étrangers et ceux qui parlent en public. Paris: Chez Jean d'Houry, 1670.

Landais Napoléon, Dictionnaire général et grammatical des dictionnaires français, Paris, 1834.

La Touche Nicolas de, Regnier-Desmarais François-Séraphim. L'art de bien parler françois, qui comprend tout ce qui regarde la Grammaire et les façons de parler douteuses. $5^{\mathrm{e}}$ édition revue et augmentée. Amsterdam: Chez J. Wetstein et G. Smith, 1730.

Le Roy Charles. Traité de l'orthographe françoise en forme de dictionnaire.

- Poitiers: Chez J. Felix Faulcon, 1747.

- Nouvelle édition considérablement augmentée sur la révision et les corrections de M. Restaut, Avocat. Poitiers: Chez François Barbier, 1792.

Milleran René. Les deux gramaires fransaizes. L'ordinaire d'à prezant, et la plus nouvelle qu'on puisse faire sans alterer, ni changer les mots. Marseille, 1694.

Olivet Pierre-Joseph Thoulier d'. Traité de la prosodie françoise avec une dissertation de Mr. Durand sur le même sujet. Geneve: Chez les frères Cramer et Cl. Philibert, 1760. [1-е изд. 1737].

Oudin Anthoine. Grammaire françoise rapportée au langage du temps. Paris: Chez Pierre Billaine, 1632.

Vallart. Grammaire françoise. Paris: Chez Desaint et Saillant, 1744.

Gillet-Vaudelin. Nouvelle manière d'écrire comme on parle en France. Paris: Vve Jean Cot et JeanBaptiste Lamesle, 1713.

Gillet-Vaudelin. Instructions cretiennes mises en ortografe naturelle: pour faciliter au peuple la lecture de la sience du salut. Paris: Chez Jean-Baptiste Lamesles, 1715.

Vaugelas Claude Favre de. Remarques sur la langue françoise, utiles à ceux qui veulent bien parler et bien escrire. Paris: Vve J. Camusat et P. Le Petit, 1647.

Wailly Noël-François. Principes généraux et particuliers de la langue française. Sixième édition revue et considérablement augmentée. Paris: Chez J. Barbou, 1772. [1-е изд. 1754]. 


\section{Литература}

Власов С. В., Московкин Л. В. Учебники русского языка для иностранцев конца XVII - начала XVIII века: адресат и лингвометодические основы // Проблемы современного образования № 6. Сетевое издание, 2014. С 79-127.

Карева Н. В., Сергеев М. Л. Первая печатная русская грамматика французского языка (1752): к вопросу о переводческих принципах В. Е. Теплова // Вестник СПбГУ. Сер. 9. 2016. Вып. 1. СПб., 2016. С. 58-69.

Панов М. В. История русского литературного произношения XVIII-XX вв. 2-е изд. М.: УРСC, 2002.

Martinet $A$. L'évolution contemporaine du système phonologique contemporain // Le français sans fard. Paris: PUF, 1969. P. 168-190.

Michaëlis H. et Passy P. Dictionnaire phonétique de la langue française. Hanover-Berlin: Carl Meyer, 1897.

Pasques $L$. L'ancienne diphtongue oi. Son évolution phonique et graphique en français moderne// Romania. T. 96. No. 381. Paris, 1975. P. 67-82.

Rey Chr. Une approche historique du concept de «Nasalité» // XXVII journées d'Étude de la Parole (JEP), Juin 2008. Avignon, France. 2016. P. 233-236.

Rjéoutski Christophe, Vlassov Sergueï. L'enseignement de la grammaire française en Russie au xvIII ${ }^{\mathrm{e}}$ siècle: enseignants, méthodes et livres utilisés // Documents pour l'histoire du français langue étrangère ou seconde, 51. Paris, 2013. P. 1-16. 